\title{
Review
}

\section{Nanoscale Imaging and Analysis of Bone Pathologies}

\author{
Victoria Garcia-Giner ${ }^{\dagger}$, Zexiang Han ${ }^{\dagger}{ }^{\mathbb{D}}$, Finn Giuliani and Alexandra E. Porter * \\ Department of Materials, Imperial College London, London SW7 2AZ, UK; \\ maria.garcia-giner17@imperial.ac.uk (V.G.-G.); zexiang.han17@imperial.ac.uk (Z.H.); \\ f.giuliani@imperial.ac.uk (F.G.) \\ * Correspondence: a.porter@imperial.ac.uk \\ + These authors contributed equally.
}

Citation: Garcia-Giner, V.; Han, Z.; Giuliani, F.; Porter, A.E. Nanoscale Imaging and Analysis of Bone Pathologies. Appl. Sci. 2021, 11, 12033. https://doi.org/10.3390/ app112412033

Academic Editor: Étienne Brès

Received: 15 November 2021 Accepted: 8 December 2021 Published: 17 December 2021

Publisher's Note: MDPI stays neutral with regard to jurisdictional claims in published maps and institutional affiliations.

Copyright: (c) 2021 by the authors. Licensee MDPI, Basel, Switzerland. This article is an open access article distributed under the terms and conditions of the Creative Commons Attribution (CC BY) license (https:// creativecommons.org/licenses/by/ $4.0 /)$.

\begin{abstract}
Understanding the properties of bone is of both fundamental and clinical relevance. The basis of bone's quality and mechanical resilience lies in its nanoscale building blocks (i.e., mineral, collagen, non-collagenous proteins, and water) and their complex interactions across length scales. Although the structure-mechanical property relationship in healthy bone tissue is relatively well characterized, not much is known about the molecular-level origin of impaired mechanics and higher fracture risks in skeletal disorders such as osteoporosis or Paget's disease. Alterations in the ultrastructure, chemistry, and nano-/micromechanics of bone tissue in such a diverse group of diseased states have only been briefly explored. Recent research is uncovering the effects of several non-collagenous bone matrix proteins, whose deficiencies or mutations are, to some extent, implicated in bone diseases, on bone matrix quality and mechanics. Herein, we review existing studies on ultrastructural imaging — with a focus on electron microscopy—and chemical, mechanical analysis of pathological bone tissues. The nanometric details offered by these reports, from studying knockout mice models to characterizing exact disease phenotypes, can provide key insights into various bone pathologies and facilitate the development of new treatments.
\end{abstract}

Keywords: bone; pathology; osteoporosis; osteogenesis imperfecta; knockout mice; non-collagenous proteins; ultrastructure; TEM; micromechanics

\section{Introduction}

Skeletal diseases affect millions of people on a global scale [1]. The risk of bone fracture is increased in diseased populations, especially for postmenopausal women who are more than 65 years of age who are more prone to develop osteoporosis [2]. In an aging population, this would translate to elevated mortality due to bone-associated morbidities [1]. In a comparative study on women in the United States, the number of incidences of osteoporotic fracture even exceeds the combined sum from stroke, heart attack, and breast cancer [3]. Additionally, for countries with universal health coverage, expenses are likely further increased for the provision of treatment options for a variety of bone disorders. The gold standard to diagnose bone disease conditions is based on changes in bone mineral density (BMD) and radiographic findings [2,4]. While the use of BMD has led to success in clinical settings, especially for osteoporotic patients, this measure neglects the ultrastructural characteristics-especially the organic phase - of bone that affects bone mechanics. As a result, BMD alone cannot categorically diagnose specific bone pathologies such as those associated with altered collagen.

Bone is a nanocomposite biomaterial with structural hierarchies ranging from the nano- to the macroscopic scale (Figure 1). It contains a multitude of cells residing in a highly heterogeneous chemical environment of hydroxyapatite minerals (50-60 wt \%), collagen (30-40 wt \%), non-collagenous proteins (NCPs), and water (10-20 vol\%) [5]. Both the mineral and organic phases within the bone contribute to the structural features (e.g., bone dimension, shape, porosity, microarchitecture) that synergize across length scales, vital for determining bone health and quality—defined as features of bone size, shape, and material 
properties that influence bone's ability to resist fracture but are not explained by BMD [6,7]. For instance, at the nanoscale, bone lamellae comprise fibrillar assemblies of elastic collagen that becomes biomineralized with stiff but brittle hydroxyapatite crystals. As a composite, the mineralized collagen fibrils combine stiffness and strength. The interplay between the two constituents and between fibrillar assemblies enables mechanisms such as fibrillar sliding, imparting toughness to bone at the sub-micrometer scale [8]. NCPs are also an important element in the ultrastructure of bone. While few hypotheses exist that explain their direct role(s) on bone quality, their physiological and mechanical importance cannot be underestimated [9]. What is known is that the whole bone tissue structure is underpinned by the integrity of these components, and disorders underlying any of these constituents can lead to poor bone quality, conducive to catastrophic fracture and other morbidities. Therefore, deciphering the structure-property relationship in healthy and diseased bone is still an ongoing process that necessitates a multiscale description of the tissue, ideally using samples in their near-native states.

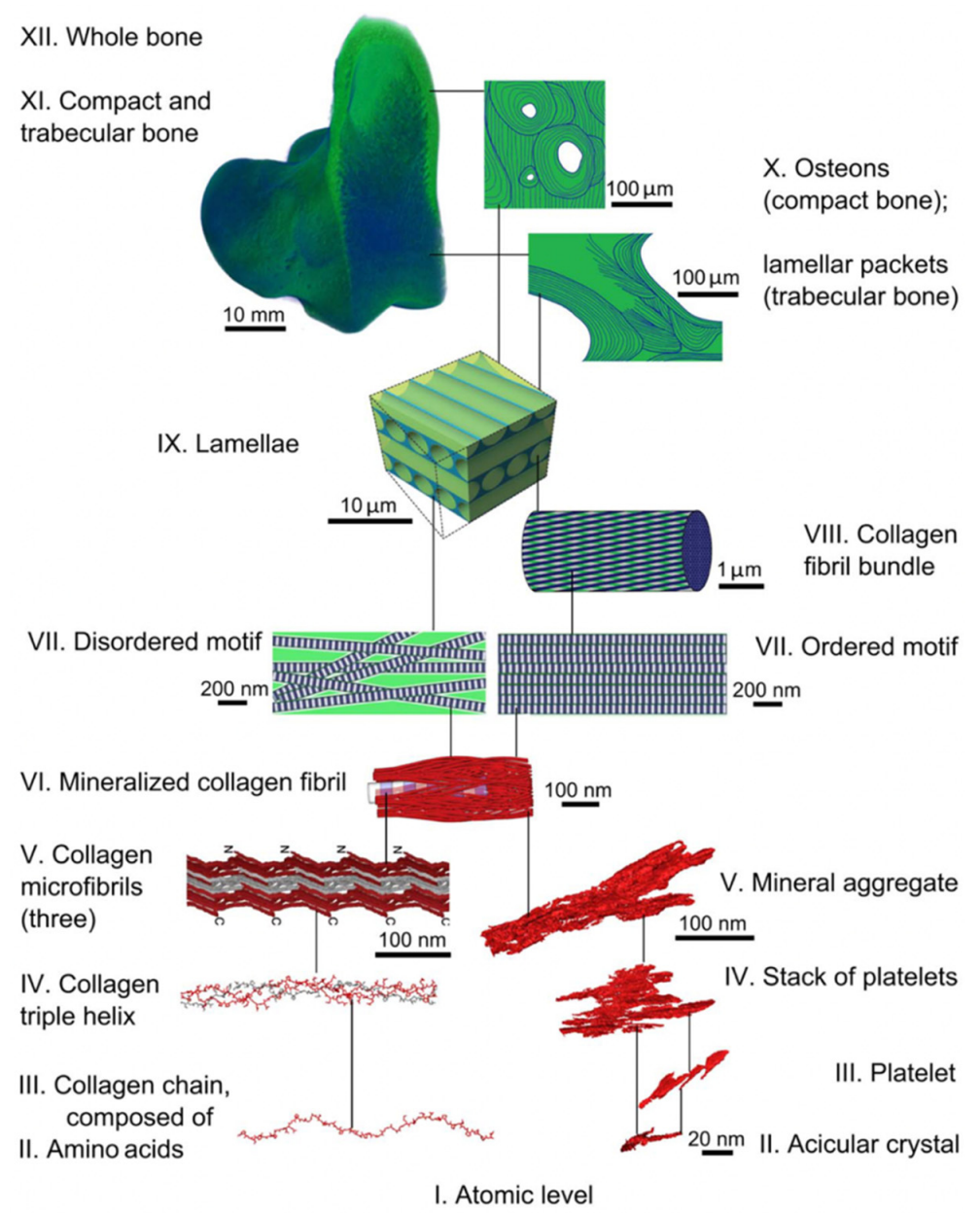

Figure 1. Hierarchical structural organization in healthy bone tissue. Schematic reprinted from [10], with permission from the American Association for the Advancement of Science.

Table 1 illustrates a suite of characterization techniques employed to investigate the physical and chemical properties of bone, starting from the nanoscale. The examples in the table also illustrate some nanostructural features for which alterations may take place in pathological bone samples. Notably, different modalities of electron microscopy-i.e., scanning, transmission, scanning transmission electron microscopy (SEM, TEM, STEM) — have been employed to successfully resolve various structural features of bone with nanometer spatial resolution despite the beam-sensitivity of the organic phase. When used in conjunction with specialized sample preparation (cryogenic conditions to immobilize thin specimens in cryo- 
TEM) or other techniques (focused ion beam (FIB) in FIB-SEM), electron microscopy enables in situ bioimaging of bone without compromising much of the spatial or temporal resolutions.

Table 1. Characterization of bone structure and chemistry from the nanoscale.

\begin{tabular}{|c|c|}
\hline Characterization Techniques & Illustrative Examples of Information Acquired \\
\hline \multicolumn{2}{|l|}{ Structure/imaging } \\
\hline Selected area electron diffraction (SAED) & $\begin{array}{ll}\text { - } & \text { Poorly crystalline nature of apatite nanocrystals }[10,11] \\
\text { - } & \text { Orientation of collagen fibrils [11] }\end{array}$ \\
\hline X-ray fiber diffraction & $\begin{array}{l}\text { - In situ structure and supramolecular arrangement of type I } \\
\text { collagen, showing quasi-hexagonal packing [12] }\end{array}$ \\
\hline $\begin{array}{l}\text { Transmission electron microscopy (TEM) and scanning } \\
\text { transmission electron microscopy (STEM) }\end{array}$ & $\begin{array}{l}\text { - Acicular crystals of apatite with approximate dimensions of } \\
\text { - } 20-30 \mathrm{~nm} \text { by } 5 \mathrm{~nm} \text { [13] } \\
\text { Distinct calcium phosphate minerals morphologies in the bone } \\
\text { extracellular matrix: dense granules, globular aggregates of } \\
\text { needle-like apatites, and mature fibrous minerals [14,15] } \\
\text { - Characteristic collagen banding pattern with a periodicity of } \\
\text { - } 67 \mathrm{~nm} \text { [16] } \\
\text { - } \text { Gap zones and overlap zones in collagen fibrils [13] } \\
\text { - } \quad \text { phase of trabecular bone [17] } \\
\text { Disorganized, entangled collagen fibrils without characteristic } \\
\text { banding pattern in the disordered phase of trabecular bone [17] }\end{array}$ \\
\hline 3D S/TEM electron tomography & - Cross-fibrillar mineralization [10] \\
\hline Cryogenic TEM & $\begin{array}{l}\text { - In situ formation of intracellular calcium phosphate } \\
\text { minerals [18] } \\
\text { - Characteristic banding pattern of collagen in its hydrated } \\
\text { state [19] }\end{array}$ \\
\hline Atomic force microscopy (AFM) & $\begin{array}{l}\text { - In situ banding pattern of hydrated collagen and its D-spacing } \\
\text { distribution }[20,21]\end{array}$ \\
\hline Scanning electron microscopy (SEM) & $\begin{array}{l}\text { - } \begin{array}{l}\text { Osteons and cement line delineating osteonal and interstitial } \\
\text { bones [22] }\end{array} \\
\text { - } \quad \text { Canalicular network with residing osteocytes [23] } \\
\text { - } \quad \text { Network organization in trabecular bone showing } \\
\text { topographical details [24] } \\
\text { - Cross-sectional photomontage of an entire human rib bone [25] }\end{array}$ \\
\hline Environmental SEM (ESEM) & $\begin{array}{l}\text { - In situ calcium phosphate mineralization in bone at } \mu \mathrm{m} \\
\text { scale [26] }\end{array}$ \\
\hline Focused ion beam SEM (FIB-SEM) & $\begin{array}{ll}\text { - } & \text { Cross-fibrillar, contiguous mineral tessellation pattern [27] } \\
\text { - } & \text { Differential collagen fibrillar alignments in lamellae and cement } \\
\text { sheath [28] } \\
\text { - } \quad \text { Prolate, ellipsoidal mineral aggregates with } \mu \text { m dimensions [29] } \\
\text { - } \quad \text { Extensive lacuno-canalicular network in mineralized bone [29] }\end{array}$ \\
\hline Polarized light microscopy & - $\quad$ Osteons showing birefringent lamellae [30] \\
\hline Scanning small-angle X-ray scattering (scanning SAXS) & $\begin{array}{l}\text { - Ultrastructural organization and 3D orientation in trabecular } \\
\text { bone at sub-mm scale [31] }\end{array}$ \\
\hline \multicolumn{2}{|l|}{ Chemical analysis } \\
\hline Electron energy-loss spectroscopy (EELS) & $\begin{array}{l}\text { - } \quad \text { Spectral information (e.g., Ca L-edge, C K-edge, O K-edge, N } \\
\text { K-edge, and P L-edge) and 1D elemental intensity profiles } \\
\text { across, e.g., the collagen D banding [16,32] } \\
\text { - Mapping of calcium, carbonate, carbonyl contents in bone } \\
\text { minerals [14,33] } \\
\text { - } \quad \text { Co-localization of N with bone minerals [14] } \\
\text { Elemental maps of proteinaceous vs. mineral contents of bone } \\
\text { and the mineralization pattern at sub- } \mu \text { m scale [34] }\end{array}$ \\
\hline
\end{tabular}


Table 1. Cont.

\begin{tabular}{|c|c|}
\hline Characterization Techniques & Illustrative Examples of Information Acquired \\
\hline Energy dispersive X-ray (EDX) spectroscopy & $\begin{array}{l}\text { - } \quad \text { Elemental microanalysis: e.g., quantification of } \mathrm{Ca} / \mathrm{P} \text { ratio [14] } \\
\text { - Similar Ca content in the cement line interior compared to } \\
\text { interstitial or osteonal bones [22] }\end{array}$ \\
\hline Quantitative backscattered electron imaging (qBEI) & $\begin{array}{l}\text { Degree of mineralization and mineral content } \\
\text { distribution }[35,36]\end{array}$ \\
\hline Raman spectroscopy and mapping & $\begin{array}{l}\text { - Raman biochemical signatures for the mineral and matrix } \\
\text { (including proteoglycans and lipids) constituents of bone, and } \\
\text { their quantitative analysis [37,38] } \\
\text { In situ transcutaneous analysis of mineral and organic contents } \\
\text { of underlying bone [39] }\end{array}$ \\
\hline $\begin{array}{l}\text { Infrared spectroscopy and mapping } \\
\quad \text { (e.g., Fourier-transform, FTIR) }\end{array}$ & $\begin{array}{l}\text { - In situ quantification of mineral content (e.g., mineral-to-matrix } \\
\text { stoichiometry) and crystallinity of bone }[40,41] \\
\text { - } \quad \text { Spatial mapping of crystalline contents }[41] \\
\text { - } \quad \text { Spatial variation in collagen maturity by measuring the ratio of } \\
\text { immature-to-mature crosslinking [42] }\end{array}$ \\
\hline Atom probe tomography (APT) & $\begin{array}{l}\text { - Chemically and spatially heterogeneous mineralization in bone, } \\
\text { showing dispersed Ca-rich and -deficient clusters of size } \\
50-70 \mathrm{~nm} \text { [43] } \\
\text { - Co-localization of Na with the mineral-collagen interface [43] }\end{array}$ \\
\hline Secondary ion mass spectroscopy (SIMS) and imaging & $\begin{array}{l}\text { - Quantification and spatial mapping of organic fragment content } \\
\left.\text { (e.g., } \mathrm{Ca}^{2+}, \mathrm{C}_{4} \mathrm{H}_{8} \mathrm{~N}^{+}\right) \text {in bone at mm scale [44] }\end{array}$ \\
\hline
\end{tabular}

Diseased bone possesses distinct structural and chemical alterations that cannot be recapitulated solely by a reduction in BMD. One of the disease manifestations is an impairment in bone mechanics, leading to greater susceptibility to fracture. For example, osteoporotic bone possesses compromised strength, and there is reduced hardness in bone with osteogenesis imperfecta pathology $[45,46]$. Since the functional link of bone structure and mechanics starts at the nanoscale, bulk mechanical techniques examining whole bone samples will fall short in isolating the effect of molecular- and fibrillar-level modifications on bone mechanics. For nano- and micromechanical testing, nanoindentation using atomic force microscopy (AFM) and micropillar compression are attractive candidates. When coupled with SEM imaging, these techniques can help visualize crack growth upon fracture ex situ and in operando [11,47]. By combining EM imaging, chemical nano-/micro-analysis, and mechanical testing of pathological bone, we can gain insights into a wide range of disease states at the bone ultrastructural level and possibly understand their origin. By analogy, characterizing bones from animals/patients treated with antiresorptive drugs, for instance, bisphosphonates, can help explain the effects of these therapeutics on bone structure and mechanics-especially considering that the long-term complications from their use remain less understood-and clarify how and to what extent they help repair diseased bone tissues [48,49].

There exists extensive literature on the multiscale characterization of healthy, normal bone tissues (Figure 1), as reviewed by others [50-52]. However, there is no systematic review emphasizing nanoscale imaging and analysis in the context of bone pathologies. In this review, we first recount the current knowledge on the roles of NCPs in bone. Next, the structural and mechanical characteristics of pathological bone tissues are discussed in relation to their healthy counterparts, highlighting the importance of ultrastructural imaging and analysis as well as the outstanding challenges in understanding bone diseases at the nanoscale. As recognizing the effects of molecular alterations in pathologic bone is critical to the design of effective, targeted therapeutics, we then discuss current and prospective strategies for repairing diseased bone. Finally, we conclude by summarizing what is known and what remains unanswered in understanding bone pathologies, starting from the nanoscale, and offer some perspectives on this topic. 


\section{The Role(s) of Non-Collagenous Bone Matrix Proteins in Bone}

2.1. Basics of Non-Collagenous Proteins

There is a plethora of NCPs in both skeletal and non-skeletal tissues, including bone, dentin, skin, tendon, cornea, and heart. Non-collagenous bone matrix proteins can be broadly classified into three main groups: glycoproteins, $\gamma$-carboxyglutamic acid (GLA)containing proteins, and proteoglycans. In bone tissues, NCPs mostly reside at the interfibrillar and extrafibrillar compartments, i.e., between collagen fibrils or decorating them, as depicted by Figure 2a,b [53]. On a microstructural level, osteopontin (OPN), for instance, can be found within the cement lines and osteon reversal regions in the osteons of trabecular bone, whereas periostin preferentially localizes in the periosteum of bone $[54,55]$.

$\mathrm{NCPs}$ are believed to partake in a wide range of processes relevant for bone formation, growth and remodeling [56,57]. Therefore, overexpression of, deficiencies in or missense mutations of one or more of these bone matrix proteins can provoke abnormal bone formation, presenting disease-like phenotypes. Deficiencies in certain NCPs, including biglycan and bone sialoprotein, also negatively impact the healing process of fractured bone [58,59].

a

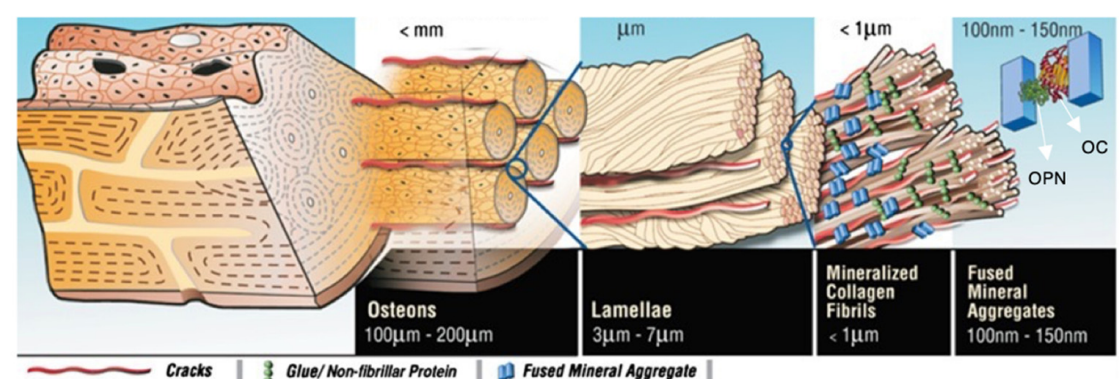

b

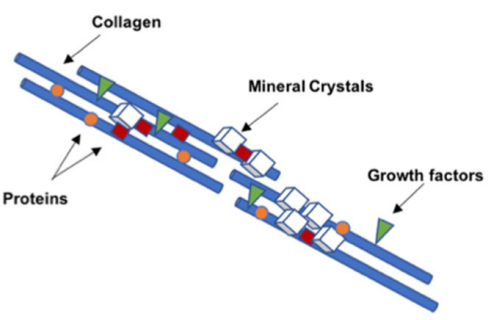

C

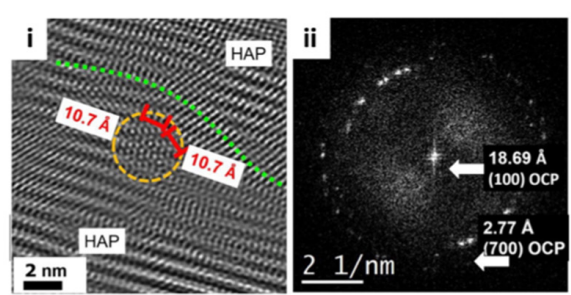

d
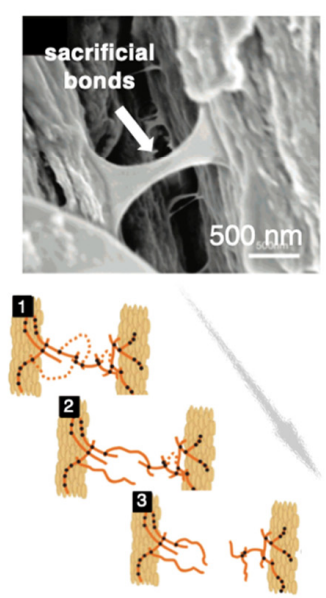

e

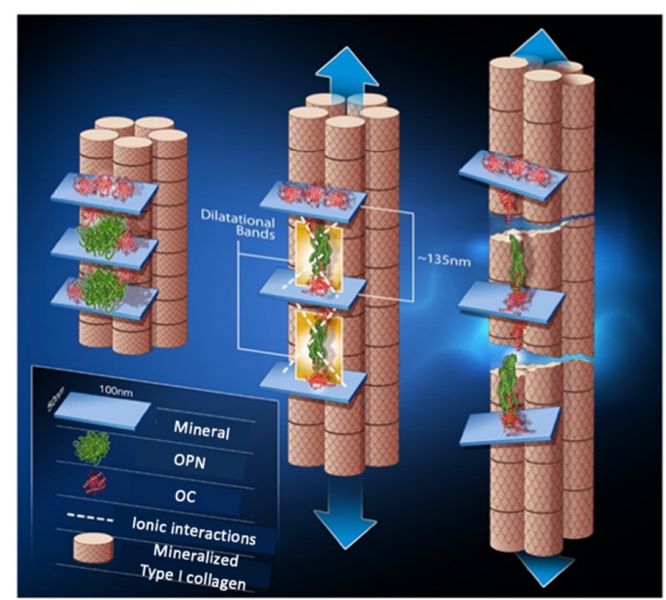

Figure 2. Non-collagenous proteins in bone. (a) A model depiction of matrix proteins OC-OPN complexes within the structural hierarchy of bone. Not to scale. Figure adapted from [60], with permission from the National Academy of Sciences of the USA. (b) Schematic showing that, ultrastructurally, NCPs are co-localized with apatite crystals, binding and bridging the collagen microfibrils. Figure reprinted from [61]. (c) Nanoscale localization of the matrix protein OC in human femur using high-resolution TEM: (i) OC proteins can be found between hydroxyapatite crystals with various 
orientations, distorting the crystal lattice; (ii) Fast Fourier transform (FFT) showing characteristic reflections, confirming the presence of osteocalcin and mineral octacalcium phosphate "OCP". Figures reprinted from [62]. (d,e) Possible structural roles of OPN and OC: (d) Intrafibrillar OPN network, and, similarly, OPN-containing NCP complexes, acting as a "glue" by forming sacrificial bonds that dissipate energy upon mechanical extension. Figures adapted from [63], with permission from the American Chemical Society. (e) OC-OPN protein complexes contribute to bone toughening under tensile stimulus via the formation of dilatational bands of $\sim 100 \mathrm{~nm}$. Figure reprinted from [60], with permission from the National Academy of Sciences.

OPN is a glycoprotein with intrinsically disordered regions. The flexibility conferred by this structural disorder and absence of a particular fold, together with its high binding affinity for $\mathrm{Ca}^{2+}$ ions, means that OPN can intricately template and guide mineral deposition, crystallization, and growth [64]. A recent study by Depalle et al. also identified OPN as an essential protein for fibrillogenesis and collagen fibril organization, not just biomineralization, in bone using transmission electron microscopy (TEM) and nanobeam electron diffraction [36]. Osteocalcin (OC) possesses a strong affinity to hydroxyapatite minerals and has been proposed to guide the alignment of apatite minerals on collagen fibrils [65]. Using high-resolution TEM, Simon et al. identified and located OC proteins, approximately $2 \mathrm{~nm}$ in diameter, in the form of connected strings attached to the tropocollagen molecules as well as in the form of individual protein globules within the mineral crystal structure (Figure 2c) [62]. Osteonectin $(\mathrm{ON})$, also known as secreted protein acidic and rich in cysteine or SPARC, accounts for $23 \%$ of NCPs in bone and is highly expressed in immature bone [66]. This observation highlights its importance in bone formation and the osteonectin-mediated binding of type I collagen to apatite crystals [67]. The roles of other NCPs have been described in recent book chapters and reviews (e.g., [57,61,68]) and will not be detailed here.

Like many other NCPs, OPN and OC are involved in bone mineral crystallization and growth. Yet what sets these two proteins apart from other NCPs-at least based on current knowledge-is that OPN and OC also have a direct structural role in bone, contributing to bone mechanics. Sitting at the collagen-mineral interface, the interfibrillar network of NCPs acts as an adhesive "glue", keeping the mineralized collagen fibrils together, and enables the formation of "sacrificial bonds" when pulling them apart under fracture (Figure 2d) [63,69]. OC and OPN, in the form of a protein complex, also regulate the formation of "dilatational bands" ( $\sim 100 \mathrm{~nm}$ ) between mineral aggregates in collagen fibrils when loaded in tension. This translates to a dissipation in energy, thereby imparting fracture toughness - that is, the ability of bone to resist fracture during initiation or propagation of a crack through the specimen-to bone at the nanoscale (Figure 2e) $[60,70]$. In investigating the structural roles of OPN and OC, experimentalists have set out to correlate nanoscale structural features of bone to nano-/micromechanics, yet we are still far from truly imaging bone in its physiological conditions at this length scale. Taking the study on the adhesion mechanism by Fantner et al. as an example, although the mechanical testing in this study was performed in buffered solutions, the specimens for SEM imaging were vacuum-dried. Nevertheless, this study does shed light on the structural role of the NCPs on bone strength.

\subsection{Effects of Non-Collagenous Proteins on Bone Structure and Mechanics}

Various skeletal disease phenotypes have been associated with a lack of or a mutation in non-collagenous bone matrix proteins, but ascertaining their precise roles in each disease remains a work in progress. Mice are widely used for modeling diseases in man due to certain anatomical, physiological and genetic parallels between the two species, rendering mice models highly effective in recapitulating human disease phenotypes [71]. Since more than 20 years ago, researchers have attempted to isolate the effects of NCPs by using genetically engineered mice with deficiency in a single NCP, i.e., single-knockout models, and compare the resulting bone with that from wild-type (WT) animals. Mice lacking two or more NCPs have also been subsequently investigated [60,65,72-78]. This is done for several reasons: first, studying double- or multiple-knockout animals can help establish 
whether the effects from single-knockouts are additive, subtractive or neither and whether there exist synergies between two or more NCPs. Secondly, processes in biological systems are almost always interdependent and confounded. A mouse lacking one NCP might and could use another NCP to carry out the same function, and exclusively studying deletions of single NCPs would fail to capture common functional redundancies. Another possibility is that the deficit in one NCP can alter the expression and/or the distribution pattern of other non-collagenous bone matrix proteins [54,58,79]; thus, identifying their exact roles would require examining a number of knockout animals. Thirdly, pertinent to studying bone pathologies, a given disease cannot be singly attributed to the absence of one NCP. Studying deficits in relevant pairs of NCPs can thus more closely mimic some pathological conditions, taking, for example, the multiple deficiencies in small leucinerich proteoglycans (SLRPs) for osteoporosis and osteoarthritis [80]. Table 2 provides an overview of the current knowledge on the deletions of one or more of some NCPs on bone properties. Additionally, associations of these NCPs—such as their mutations, overexpression, and down-expression or deficiencies-to bone diseases in mice models and in man have been summarized.

Table 2. The effects of the deletions/deficiencies of some NCPs on bone structure, chemistry, and mechanics ${ }^{1}$.

\begin{tabular}{|c|c|c|c|c|c|}
\hline $\begin{array}{l}\text { NCPs and } \\
\text { References }\end{array}$ & $\begin{array}{l}\text { Whole-Bone } \\
\text { Structure }\end{array}$ & $\begin{array}{c}\text { Ultrastructure } \\
\text { (and Microstructure) }\end{array}$ & $\begin{array}{l}\text { Chemistry and } \\
\text { Composition }\end{array}$ & $\begin{array}{l}\text { Mechanical } \\
\text { Properties }^{2}\end{array}$ & $\begin{array}{l}\text { Related Bone } \\
\text { Diseases }^{3}\end{array}$ \\
\hline \multicolumn{6}{|l|}{ Single knockouts } \\
\hline $\begin{array}{c}\text { Osteopontin } \\
\text { OPN }^{-/-} \\
{[36,65,72,81,82]}\end{array}$ & $\begin{array}{l}\text {-bone mass } \\
\text { - porosity }\end{array}$ & $\begin{array}{l}\downarrow \text { apatite crystal size } \\
-/ \downarrow \text { apatite crystal } \\
\text { thickness } \\
\uparrow \text { crystal misorientation } \\
\text { —collagen fibril width } \\
\text { —collagen D banding } \\
\text { Disorganized and more } \\
\text { heterogeneous matrix }\end{array}$ & $\begin{array}{l}-/ \downarrow \text { mineralization } \\
\downarrow \text { collagen content } \\
\text { Variability in } \mathrm{Ca} \\
\text { concentration }\end{array}$ & 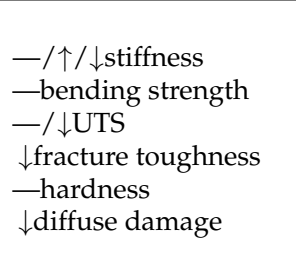 & $\begin{array}{c}\text { Osteoporosis } \\
\text { Osteoarthritis }[83,84]\end{array}$ \\
\hline $\begin{array}{c}\text { Osteocalcin } \\
\text { OC }^{-/-} \\
{[65,85-88]}\end{array}$ & $\begin{array}{l}\uparrow \text { bone mass } \\
\uparrow \text { cortical bone } \\
\text { thickness }\end{array}$ & $\begin{array}{l}\downarrow \text { crystal size } \\
\downarrow \text { crystal thickness } \\
\text { Altered crystal } \\
\text { morphology } \\
\uparrow \text { crystal misorientation }\end{array}$ & $\begin{array}{l}\text { - } / \downarrow \text { mineralization } \\
\text { - } / \downarrow \text { mineral: matrix } \\
\text { ratio } \\
\downarrow \text { mineral maturity } \\
\uparrow / \downarrow \text { crystallinity } \\
\downarrow \text { carbonate in mineral } \\
\text { - trace element } \\
\text { concentrations ( } \mathrm{Mg}, \mathrm{Na} \text {, } \\
\mathrm{S}, \mathrm{F}) \\
\text { Homogenization in } \\
\text { mineral distribution } \\
\text { from periosteum to } \\
\text { endosteum }\end{array}$ & $\begin{array}{l}-/ \downarrow \text { stiffness } \\
\text { —/ } \text { bending strength } \\
\uparrow \text { hardness } \\
\downarrow \text { diffuse damage }\end{array}$ & Osteoporosis [89] \\
\hline $\begin{array}{l}\text { Osteonectin } \\
\mathrm{ON}^{-/-} \\
\left(\mathrm{SPARC}^{-/-}\right) \\
\text {[90-92] }\end{array}$ & $\begin{array}{l}\downarrow \text { bone mass } \\
\downarrow \text { trabecular } \\
\text { number } \\
\downarrow \text { femoral length } \\
\text {-cortical bone } \\
\text { thickness }\end{array}$ & $\mathrm{N} / \mathrm{A}$ & $\begin{array}{l}\uparrow / \downarrow \text { mineralization } \\
\downarrow \text { mineral: matrix ratio } \\
\uparrow / \downarrow \text { crystallinity } \\
\downarrow \text { collagen content } \\
\downarrow \text { collagen crosslinking } \\
\uparrow \text { spatial heterogeneity } \\
\text { in collagen maturity }\end{array}$ & $\begin{array}{l}\downarrow \text { stiffness } \\
\text { —/ } \downarrow \text { bending strength } \\
\text { —UTS } \\
\uparrow \text { failure strain }\end{array}$ & $\begin{array}{l}\text { Osteoporosis } \\
\text { OI } \\
\text { Osteopenia } \\
{[90,91,93,94]}\end{array}$ \\
\hline $\begin{array}{l}\text { Biglycan } \\
\text { Bgn }^{-/-} \\
{[74,95-98]}\end{array}$ & $\begin{array}{l}\downarrow \text { bone mass } \\
-/ \downarrow \text { bone length } \\
\text { Poor trabecular } \\
\text { connectivity }\end{array}$ & $\begin{array}{l}\uparrow \text { collagen fibril } \\
\text { diameter } \\
\uparrow \text { variation in diameter } \\
\text { and shape of fibril } \\
\text { Abnormal collagen } \\
\text { packing }\end{array}$ & $\begin{array}{l}-/ \downarrow \text { mineralization } \\
\downarrow \text { glycosaminoglycans, } \\
\text { especially chondroitin } \\
\text { sulfate } \\
\downarrow \text { bound water }\end{array}$ & $\begin{array}{l}\text { —stiffness } \\
\text { —/ } \text { bending strength } \\
\downarrow \text { ductility } \\
\text { —post-yield } \\
\text { deformation }\end{array}$ & $\begin{array}{c}\text { Osteoporosis } \\
\text { Osteopenia } \\
{[74,97,99]}\end{array}$ \\
\hline $\begin{array}{l}\text { Periostin } \\
\text { Postn }^{-/-} \\
{[100-103]}\end{array}$ & $\begin{array}{l}\downarrow \text { bone mass } \\
-/ \downarrow \text { cortical and } \\
\text { trabecular bone } \\
\text { thickness } \\
\downarrow \text { trabecular } \\
\text { number }\end{array}$ & $\begin{array}{l}\downarrow \text { orientational } \\
\text { alignment in lacunae }\end{array}$ & $\begin{array}{l}\downarrow \text { mineralization } \\
\downarrow \text { collagen crosslinking }\end{array}$ & $\begin{array}{l}-/ \downarrow \text { stiffness } \\
-/ \downarrow \text { bending strength } \\
-/ \downarrow \text { plastic energy } \\
\downarrow \text { fatigue properties }\end{array}$ & $\begin{array}{c}\text { Osteoarthritis } \\
\text { Osteosarcoma } \\
{[102,104]}\end{array}$ \\
\hline
\end{tabular}


Table 2. Cont.

\begin{tabular}{|c|c|c|c|c|c|}
\hline $\begin{array}{l}\text { NCPs and } \\
\text { References }\end{array}$ & $\begin{array}{l}\text { Whole-Bone } \\
\text { Structure }\end{array}$ & $\begin{array}{c}\text { Ultrastructure } \\
\text { (and Microstructure) }\end{array}$ & $\begin{array}{l}\text { Chemistry and } \\
\text { Composition }\end{array}$ & $\begin{array}{l}\text { Mechanical } \\
\text { Properties }^{2}\end{array}$ & $\begin{array}{c}\text { Related Bone } \\
\text { Diseases }^{3}\end{array}$ \\
\hline $\begin{array}{c}\text { Tissue-nonspecific } \\
\text { alkaline phosphatase } \\
\text { TNAP-/- } \\
{[54,78,105]}\end{array}$ & $\begin{array}{l}\downarrow \text { femoral length } \\
\downarrow \text { trabecular bone } \\
\text { thickness }\end{array}$ & $\begin{array}{l}\text { —crystal thickness } \\
\uparrow \text { crystal misorientation } \\
\text { Spatial variation in } \\
\text { crystal misalignment } \\
\text { Altered morphology of } \\
\text { mineral granules }\end{array}$ & $\begin{array}{l}\downarrow \text { mineralization } \\
\downarrow \text { mineral: matrix ratio } \\
\text { —crystallinity } \\
\uparrow \text { Ca concentration } \\
\text { Altered spatial } \\
\text { distribution of } \\
\text { crystalline regions }\end{array}$ & $\mathrm{N} / \mathrm{A}$ & $\begin{array}{l}\text { Osteopenia } \\
\text { HPP } \\
\text { Rickets } \\
\text { Osteomalacia } \\
\text { [106-108] }\end{array}$ \\
\hline $\begin{array}{c}\text { Dentin matrix } \\
\text { protein } 1 \\
\text { DMP } 1^{-/-} \\
{[23,109]}\end{array}$ & $\begin{array}{l}\downarrow \text { bone volume } \\
\downarrow \text { bone length } \\
\text { Altered bone } \\
\text { cross-sectional } \\
\text { shape } \\
\text { Enlarged } \\
\text { metaphysis }\end{array}$ & $\begin{array}{l}\uparrow \text { crystal size } \\
\text { Irregular } \\
\text { mineralization pattern } \\
\text { Disorganized } \\
\text { lacuno-canalicular } \\
\text { network (LCN) } \\
\text { Decreased number of } \\
\text { dendrites in LCN } \\
\text { Absence of lamina } \\
\text { limitans }\end{array}$ & $\begin{array}{l}\downarrow \text { mineralization } \\
\downarrow \text { mineral: matrix ratio } \\
\uparrow \text { crystallinity } \\
\text { —collagen crosslinking } \\
\downarrow \text { Ca concentration } \\
\text { Abnormal distribution } \\
\text { of phosphorus }\end{array}$ & $\mathrm{N} / \mathrm{A}$ & $\begin{array}{c}\text { Rickets } \\
\text { Osteomalacia } \\
\text { Osteoarthritis } \\
{[23,110]}\end{array}$ \\
\hline \multicolumn{6}{|l|}{ Double knockouts } \\
\hline $\begin{array}{c}\mathrm{OC}-\mathrm{OPN}^{-/-;-/-} \\
{[60,65,72]}\end{array}$ & $\begin{array}{l}\text {-bone length } \\
\text {-cortical bone } \\
\text { thickness }\end{array}$ & $\begin{array}{l}\downarrow \text { crystal thickness } \\
\uparrow \text { crystal misorientation } \\
\text { Altered crystal } \\
\text { morphology }\end{array}$ & $\begin{array}{l}\text { —mineralization } \\
\text { —trace element } \\
\text { concentrations }\end{array}$ & $\begin{array}{l}\text { —stiffness } \\
\text { — bending strength } \\
\downarrow \text { fracture toughness } \\
\downarrow \text { diffuse damage }\end{array}$ & $\begin{array}{c}\text { Osteoporosis } \\
{[83,89]}\end{array}$ \\
\hline $\begin{array}{c}\text { Bgn-Dcn }-/-;-/- \\
{[74,111]}\end{array}$ & $\downarrow$ bone mass & $\begin{array}{l}\text { Altered collagen fibril } \\
\text { morphology } \\
\text { Uniform "glassy" } \\
\text { appearance of } \\
\text { mineralized matrix }\end{array}$ & $\downarrow$ mineralization & $\mathrm{N} / \mathrm{A}$ & $\begin{array}{c}\text { Osteopenia } \\
{[74,111]}\end{array}$ \\
\hline $\begin{array}{c}\text { TNAP-NPP1 } 1^{-/-;-/-} \\
{\text {(TNAP-PC } 1^{-/-;-/-} \text {) }}_{[77,78]^{4}}\end{array}$ & $\begin{array}{l}\downarrow \text { bone volume } \\
\downarrow \text { trabecular } \\
\text { thickness }\end{array}$ & $\begin{array}{l}\text { Altered mineral } \\
\text { morphology: more } \\
\text { granule-like }\end{array}$ & $\begin{array}{l}\downarrow \text { mineralization } \\
\downarrow \text { mineral: matrix ratio }\end{array}$ & $\mathrm{N} / \mathrm{A}$ & $\begin{array}{c}\text { Osteomalacia } \\
{[78]}\end{array}$ \\
\hline
\end{tabular}

${ }^{1}$ Symbols: $\uparrow$ for increase; $\downarrow$ for decrease; and-for no significant change in value (almost all studies reported here used $\left.p<0.05\right)$.

2 Abbreviations for mechanical parameters: UTS = ultimate tensile strength. ${ }^{3}$ Abbreviations for bone diseases: OI $=$ osteogenesis imperfecta; HPP = hypophosphatasia. ${ }^{4}$ NPP1 = nucleotide pyrophosphatase phosphodiesterase 1, previously known as plasma cell membrane glycoprotein 1 (PC-1), encoded by the Enpp gene.

Out of all NCPs, bone matrix proteins OPN and OC have been subject to more extensive investigations. The first systematic study describing OPN-deficient bone was published in Nature in 1996 [85], and numerous reports have since ensued. Consider OPN-deficient mice, even though the morphological traits of bone at the macroscale remained similar to those of WT bone, ultrastructural and chemical alterations were detected at the nanoscale. Smallangle $\mathrm{X}$-ray scattering analysis confirmed a reduction in the mineral crystal later size and an increase in the mineral misorientation within the mineralized collagen matrix $[65,81]$. This was recently corroborated by nanobeam electron diffraction analysis to correlate directly with the disorganized collagen fibrillar structure in $\mathrm{OPN}^{-/-}$bone, imaged using TEM (Figure 3a) [36]. In the absence of OPN, the previously mentioned "glue-like" mechanism of OPN bridging collagen fibrils, as well as the toughening mechanism by dilatational band formation, would likely be nullified. Together with the disordered texture of mineralized collagen fibrils, OPNknockout bone possesses impaired mechanics, specifically a reduction in fracture toughness. There is a similar abundance of findings on the chemical changes in both $\mathrm{OPN}^{-/-}$and $\mathrm{OC}^{-/-}$ bone, yet no collagen fibril-level information has been acquired for $\mathrm{OC}^{-/-}$bone. Despite this, key insights into how OC-deficiency induces pathological changes in the mineral phase have been plenty (Table 2), validating hypotheses that $\mathrm{OC}$ regulates mineralization. In double knockout models of OC-OPN ${ }^{-/-;-/-}$mice, co-dependent control over mineralization by OPN and OC has been suggested; yet the two proteins seemed to govern independently the morphology of the semicrystalline minerals formed [65]. In addition, even though there were many shared traits in $\mathrm{OPN}^{-/-}$and $\mathrm{OC}^{-/-}$bone compared to normal WT bone, their deleterious effects on bone ultrastructure and mechanical properties were generally non- 
additive. This is evidenced by results from both quantitative ultrastructural analysis and mechanical testing (Figure 3b,c). Such an observation alludes to the general degeneracies of biological systems and the possible functional redundancies between NCPs mentioned previously [112]. Poundarik et al. also revealed that the formation of bone minerals remained unimpeded in the absence of both matrix proteins despite defective changes to the crystal shape, dimensions, and orientation [65]. Therefore, it is reasonable to assume that other NCPs may play a similarly important role in bone mineral formation and collagen mineralization.

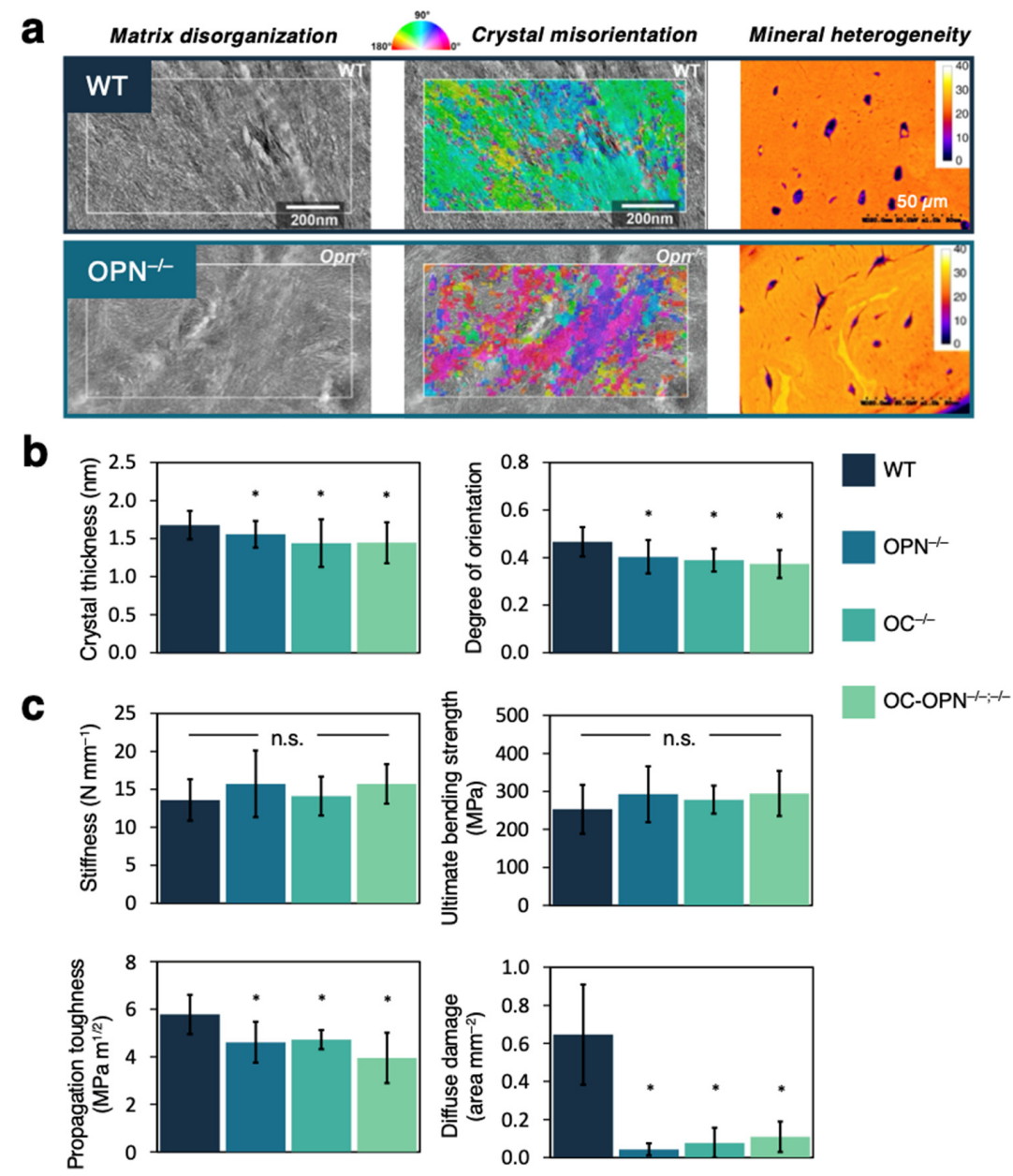

Figure 3. Deficiencies of OPN and OC in bone of knockout mice models. (a) Resolving OPN-deficiencyinduced ultrastructural changes in bone using TEM (left), nanobeam electron diffraction (middle), and qBEI imaging (right). Figures reprinted from [36,81], with permissions from Elsevier. (b) Quantitative analysis on the bone ultrastructure, i.e., mineral crystal thickness and orientation, in $\mathrm{WT}, \mathrm{OPN}^{-/-}$, $\mathrm{OC}^{-/-}$, and OC-OPN ${ }^{-/-}$mice. Degree of orientation, the so-called $\rho$-parameter, is calculated from SAXS patterns. Figures are replotted using data from [65]. (c) Mechanical properties of bone in WT, $\mathrm{OPN}^{-/-}, \mathrm{OC}^{-/-}$, and $\mathrm{OC}-\mathrm{OPN}^{-/-}$mice: stiffness, ultimate bending strength, propagation toughness, and diffuse damage upon fatigue. Figures are replotted using data from [60,72]. Asterisk * indicates a statistically significant difference compared to WT, with $p<0.05$. n.s. = not significant.

Other commonly studied pairs of NCPs are combinations of SLRPs such as biglycan (Bgn) and decorin (Dcn). Decorin (Dcn) is highly homologous to Bgn, containing one chondroitin sulfate chain attached near its amino terminal group instead of two in Bgn. However, the conformational folds for the two NCPs are dissimilar [113]. One would imagine that comparing and contrasting the effects of Bgn- and Den-deficiencies on bone quality could offer interesting insights into their functional roles. Unfortunately, there currently exists minimal information on how bone ultrastructure, chemistry, and mechanics are altered in the single knockout $\mathrm{Dcn}^{-/-}$ despite numerous reports for its close relative Bgn. In one study cross-examining both SLRPs, 
$\mathrm{Dcn}^{-/-}$mice retained their bone mass, suggesting the absence of an osteopenia-like state, whereas a reduction in bone mass was recorded for $\mathrm{Bgn}^{-/-}$mice [74]. In the same study, the collagen fibril diameter also decreased by $12 \%$ for $\mathrm{Dcn}^{-/-}$but increased by $10 \%$ for $\mathrm{Bgn}^{-/-}$compared to the WT control. The irregular collagen formation observed might offer a partial explanation to the association of Dcn-deficiency with osteogenesis imperfecta [114], and additional ultrastructural information is needed but missing in this area. Markedly distinct effects of Bgn and Don deficiencies on bone were found, even though highly similar effects were seen in the dermis [74]. In studying the Bgn-Dcn ${ }^{-/-;-/-}$double knockouts, the aforementioned effects from single knockouts were found to be additive and, in fact, synergistic in bone tissues. The onset of the osteopenic state was much earlier in Bgn-Dcn ${ }^{-/-;-/-}$mice compared to in $\mathrm{Bgn}^{-/-}$mice in spite of no apparent bone loss in Dcn ${ }^{-/-}$mice [115]. Thus, understanding the mechanism for this observed synergy is of considerable importance in light of the fact that functional synergies between NCPs are not guaranteed, as seen in OPN-OC double-deficient mice, and currently remain unpredictable.

A rather limited number of studies report findings on other double-knockout models, including osteopontin-bone sialoprotein ${ }^{-/-;-/-}\left(\mathrm{OPN}^{-\mathrm{BSP}^{-/-} ;-/-}\right)$, biglycan-epiphycan $-/-;-/-$, biglycan-fibromodulin ${ }^{-/-;-/-}$, and TNAP-NPP1 $1^{-/-;-/-}[73,76-78,111]$. For OPNBSP double-deficient mice, subtractive or compensatory effects were observed for the wholebone architectural parameters: as an example, $\mathrm{OPN}^{-/-}$mice possessed significantly higher $\mathrm{BMD}$, and $\mathrm{BSP}^{-/-}$mice possessed lower BMD compared to WT. In OPN-BSP ${ }^{-/-;-/-}$mice, the BMD was still lower than in WT, but the value was in between those of single NCP deficiencies [73]. This suggests potential functional compensation between the two NCPs. Biglycan-epiphycan double-deficiency is implicated in osteoarthritis, as are its single-knockout counterparts. In a male mice model lacking both SLRPs, the severity of osteoarthritis proved significantly higher in the double-deficient mice than both singly-deficient mice [76]. These examples thus again highlight the necessity of studying double knockouts in the context of bone physiology and pathology. Yet, there is a paucity of ultrastructural details in these studies-for example, the description of collagen fibril orientation, arrangement, and organization-and mechanical characterization of bones at both the micro and tissue levels. We are still far from understanding the effects of such deficiencies on bone structure and mechanics.

\subsection{Discrepant Results in the Literature and the Path Forward}

Closer scrutiny of the findings reported in Table 2 reveals that there are discrepancies and sometimes diverging results (i.e., studies claiming an increase, decrease, or non-change in the same parameter) between different reports. This has also been recently pointed out by Moriishi and Komori in a comment piece, noting the lack of reproducibility in the results of bone properties in $\mathrm{OC}^{-/-}$mice [116]. Several factors may contribute to the observed differences: briefly, intrinsic factors such as the nature and state of the specimen and the anatomical site of bone, as well as extrinsic factors such as the techniques employed to characterize the sample and the associated sample preparation. The inbred strain, age, and gender of the knockout mice models used can greatly impact the resulting attributes of bone, as demonstrated by $\mathrm{Bgn}^{-/-}$mice $[96,117]$. In addition, the sample preparation can introduce artifacts into the sample to be imaged/analyzed. One aspect that eludes most studies is the hydration state of bone. Bone is an inherently hydrated material that will dehydrate in the high vacuum environment of the electron microscope, and the degree of hydration of bone influences its structure and mechanical behavior, especially tissue viscoelasticity. Recently, the presence of bound water and its significance in determining the bone mechanics of WT and SLRP-knockout mice have been demonstrated, highlighting the differential roles of bound water versus simple hydration in bone toughness [98]. Lastly, the length scale at which characterization has been carried out is crucial for correctly interpreting the results. Some results are not in actuality debatable; rather, they are inferred results tested at different levels of bone's structural hierarchy using whole-bone vs. sectioned/machined samples [118]. It can be concluded that, following the principle that "smaller-is-stronger", the mechanisms of bone failure differ at different length scales, 
showing higher strength and ductility in smaller specimens when only tissue was inspected. This small-scale characterization can only be attained with the use of electron microscopy, which provides resolutions lower than the limit diffraction of light $(<200 \mathrm{~nm})$.

The semi-conflicting results in the literature and their lack of reproducibility highlight the need for correlative experiments where imaging, chemical analysis, and mechanical testing are performed simultaneously within the same electron microscope sample holder. Here, we suggest some specific strategies. To address the problem of sample dehydration, a one-hour to overnight immersion of specimens in phosphate-rich water solution is the standard procedure followed prior to mechanical testing [119], although the possible effect of this procedure on demineralization has not been quantified. Constant dripping or complete submersion of the hydrating media during macroscale testing is also widely accepted as a technique to rehydrate the bone $[120,121]$. These procedures appear to be effective in keeping the specimens wet at the macroscale but when the length scale of the test is reduced to a few $\mu \mathrm{m}$, adapting these same procedures to retain water becomes a real challenge. For correlative imaging-mechanical testing, improvements and advances in electron microscopy have enabled us to test the mechanical properties of hydrated bone specimens in these microscopes. One emerging technique is liquid-phase electron microscopy-including environmental SEM (ESEM) and liquid-cell electron microscopy-for multimodal and correlative analysis of undecalcified and hydrated bone samples [122,123]. These emerging electron microscopy modalities show great promise for the imaging of biomaterials in their near-native states without following the harsh sample preparation protocol as in conventional EMs, which operate under high vacuum and without significant compromise of the spatial and temporal resolutions [123].

Moreover, in situ micromechanical testing such as nanoindentation, uniaxial compression, and fracture can be coupled to ESEM to allow the direct visualization of, e.g., crack initiation and propagation as well as simultaneous structural-mechanical analysis within the same microscope $[119,121]$. Simple nanoindentation can provide information on hardness, elastic moduli, and plastic deformation based on the load-displacement curve created by the incision of a sharp tip of micrometric dimensions to a bone surface $[118,124]$. Fewer research groups have attempted other uniaxial compression/tension tests, such as pillar compression and tensile testing of micrometric bone specimens $[125,126]$. However, these uniaxial tests can provide information on the anisotropic micromechanical properties of bone tissue as the longitudinal and transversal directions of bone can be isolated through fabrication. A similar approach has also been used to understand the fracture toughness of bone at this length scale [11]. To perform these studies, continuous monitoring of the stable crack growth during the fracture of the bone specimen is required, which can only be achieved through an in situ micromechanical experiment inside the EM due to the dimensions of the specimen under study. Despite the difficulties that these experiments entail, in situ study of deformation and fracture at the microscale can open up the possibility of isolating bone tissue from its extrinsic toughening mechanisms and provide a better understanding of the effect of genetic diseases and protein malfunctions in bone. Detailed mechanistic insights into previously observed/proposed synergies in NCP pairs on bone structure and mechanics can also be obtained. Provided that the genetic background and state of the knockout mice are explicitly stated and uniform between studies, in situ correlative imaging, chemical mapping, and mechanical analysis of hydrated bone should help resolve the equivocal effects of NCP deficiencies on bone and further the understanding thereof.

\section{Bone Pathologies: Alterations to Bone Ultrastructure and Mechanics}

\subsection{Osteoporosis}

Osteoporosis, a chronic metabolic bone disorder, is clinically diagnosed using BMD values, where a BMD greater than or equal to 2.5 standard deviations below the normative reference is indicative of an osteoporotic bone [127]. However, osteoporosis affects bone quality starting at the ultrastructural scale, at least five or six orders of magnitude below the centimeter scale at which an averaged BMD is evaluated. In addition, osteoporosis is a complex disease in that not all osteoporotic bones are the same because there exist multiple 
types of osteoporosis: senile, postmenopausal, and steroid-induced (more specifically glucocorticoid-induced). For instance, senile osteoporosis exhibits more significant cortical bone loss, whereas, for postmenopausal women, the bone loss mainly takes place in the trabecular region, giving rise to differential fracture risks [127]. Such complication necessitates an understanding of the disease starting at the nanoscale.

There appear to be plenty of works on the nanoscale imaging of osteoporotic bone, but the underlying differences in the sample types render comparison and cross-examination difficult, especially considering that the findings are non-uniform. Some employ human patient samples for which idiopathic/general osteoporosis predominates, while others use animals to model a more specific type of osteoporosis. In what follows, we will draw commonalities in results and discuss case-by-case ultrastructural and chemical changes in osteoporotic bones.

Examining bones from osteoporosis patients, Rubin et al. concluded that there were no discernible ultrastructural differences between healthy and osteoporotic bone for both the mineral and collagen phases of bone [128]. However, this is not the case in animal models of specific subtypes of osteoporosis. Consider first the mineral phase of hydroxyapatites, where a suite of studies has inspected crystal dimensions, morphology, mineral arrangement and packing, orientation patterns, and the degree of mineralization [128-131]. Using small-angle X-ray scattering (SAXS), Xi et al. measured shorter apatite crystals with increased thickness in steroid-induced osteoporotic mouse bone, and an overall change in the crystal morphology was ascertained [129]. In the same study, the authors established a positive correlation between the length and thickness of the apatite nanocrystals [129], suggesting that the apatite volume was not conserved in steroid-induced osteoporotic bone as in normal WT bone. Thus, there may be fundamental changes to the mineralization process in osteoporosis pathology, which is sensible, given that both OPN and ON deficiencies correlate well with an osteoporotic phenotype (Section 2.2). In an ovariectomized mouse model of postmenopausal osteoporosis, the nanocrystallites were found to be more spatially dispersed compared to their tightly-packed counterpart in WT bone (Figure 4(ai)) [130]. For mineralized collagen fibrils, the mineralization pattern can be quantified by the crystal orientation angles - though such information is, in reality, three-dimensional due to the cross-fibrillar nature of the minerals deposited. Rubin et al. did not observe any qualitative change in crystal orientations in human osteoporotic samples, but incidences of slight increase in mineral misorientation were visualized in high-resolution TEM for bone from a postmenopausal osteoporotic mouse [128-130]. Only SAXS has been used to directly quantify and map misorientation angles of the nanocrystals in a steroid-induced osteoporotic mouse (Figure 4(aii)) [129]. Given the above information, this may suggest that the mineralization processes are different for different types of osteoporosis. Nevertheless, one must remain cautious since the great disparity in the sample statistics and techniques employed to examine the same ultrastructural detail render any rational comparisons difficult. More systematic work is required to clarify this.

Starting at the molecular scale, tropocollagen molecules that self-assemble into collagen fibrils and subsequently into collagen fibers can be intrinsically defective as a result of defects in the COL1A1 gene that encodes for the $\alpha 1$ type I collagen, where the gene is associated with osteoporosis in man [132]. Early work on biochemical analysis revealed a reduction in the quantity of Type I collagen, as well as decreased amount of total collagen crosslinks in idiopathic osteoporotic bone compared to healthy bone [133]. An overall elevated collagen maturity was also detected due to an increased level of mature pyridinoline crosslinking and a reduction in immature dihydroxylysino-norleucine (DHLNL) crosslinking [133], where the degree of such enzymatic crosslinking directly impacts fibril mechanics [134]. In both senile and ovariectomy-induced (postmenopausal) mice, irregularities in collagen fibril morphologies were observed: the collagen fibrils were, on average, shorter and possessed a reduced diameter compared to normal counterparts (Figure 4(aiii)) $[130,133,135]$. The cross-sectional TEM image of the collagen fibrils shown in Figure 4a also revealed a loss of their characteristic quasi-hexagonal packing, leading to a disordered arrangement in the transverse direction. In the longitudinal direction, the fib- 
rillar texture was also more random in osteoporotic bone (Figure 4(aiv)) [130,133,135]. This was further validated using spatially-resolved SAXS maps in a mouse model with excessive endogenous steroids [129]. On average, the mineral-to-matrix ratio is lower in osteoporotic bone than in normal bone (Figure 4(bii)), with bone mineral density distribution shifting to lower values, indicating a hypomineralized bone (Figure 4(bi)). Time-of-flight secondary ion mass spectrometry (ToF-SIMS) has been used to distinguish between local chemical features in normal and osteoporotic bone [44]. Compared to the typical spatial resolution of 1-10 $\mu \mathrm{m}$ for vibrational spectroscopic imaging (e.g., FTIR), the lateral resolution can reach less than $300 \mathrm{~nm}$ for ToF-SIMS imaging, elucidating sub- $\mu \mathrm{m}$ scale variations in chemistry.

\section{a}

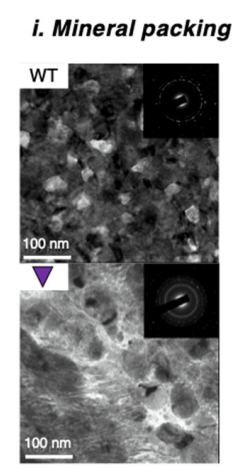

ii. Crystal misorientation

iii. Collagen fibril morphology
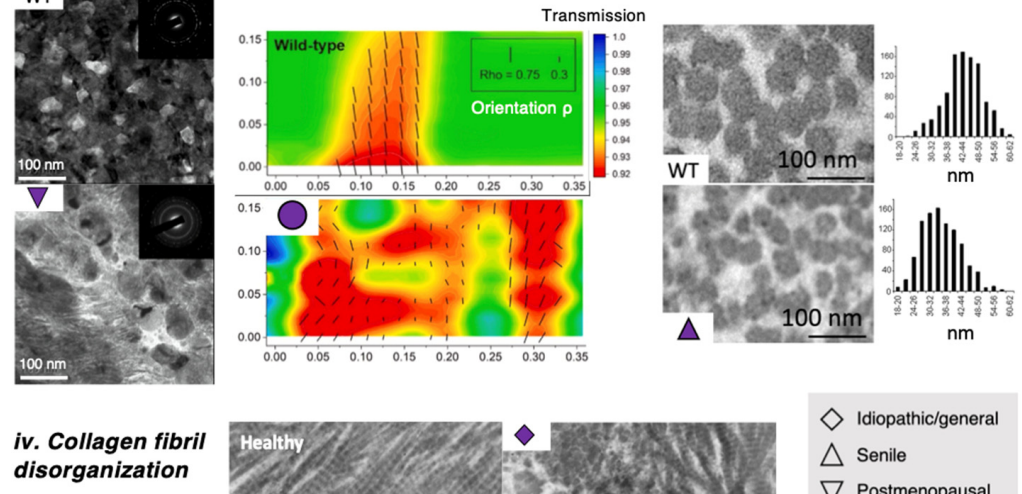

disorganization
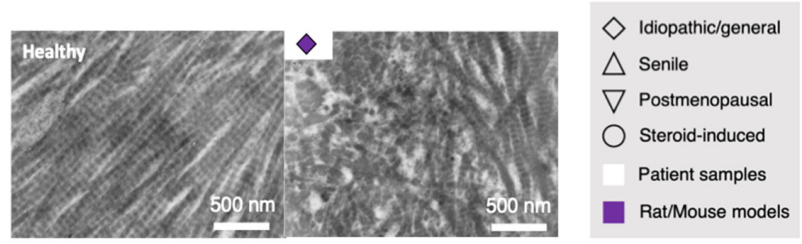

b

ii. Mineral crystallinity iii. Mineral: matrix ratio
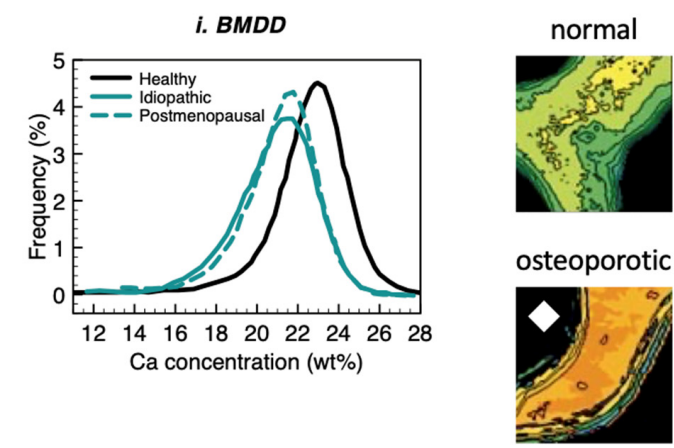

normal

$400 \mu \mathrm{m} \times 400 \mu \mathrm{m}$

C
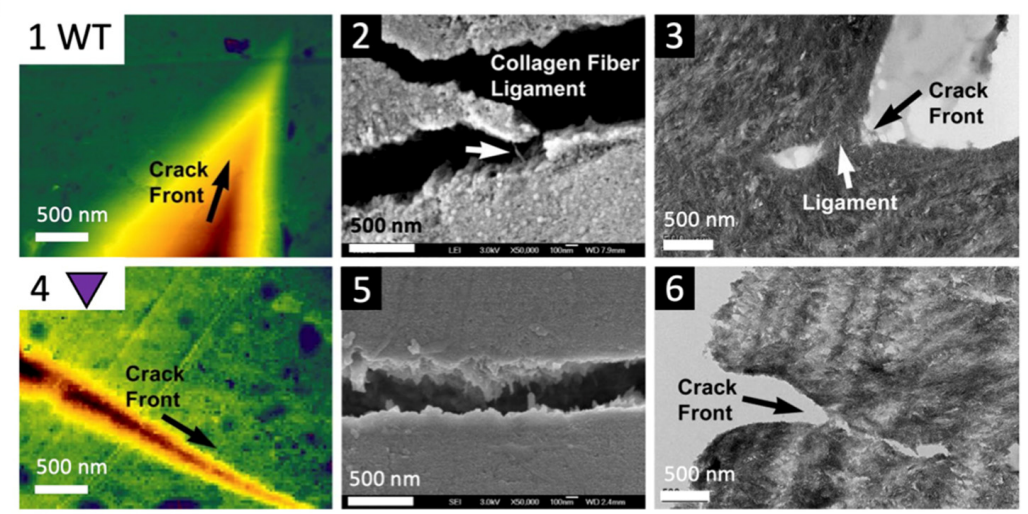

Figure 4. Altered bone ultrastructure, chemistry, and nanomechanics in osteoporosis pathology. (a) Ultrastructural changes: (i) high-resolution TEM images and SAED patterns of the cortical bone 
from sham/WT mice and ovariectomized postmenopausal osteoporotic mice, showing differences in the packing arrangement of the mineral nanocrystals. Figures reprinted from [130], with permission from the American Chemical Society. (ii) Superimposed X-ray intensity contour map and quiver plot showing mineral crystal orientation in WT vs. steroid-induced osteoporotic bone. Figures reprinted from [129], with permission from Elsevier. (iii) TEM images of collagen fibrils and the corresponding histograms for collagen fibril diameter. Figures reprinted from [133], with permission from Taylor \& Francis. (iv) TEM images of collagen fibrillar organizations in healthy vs. osteoporotic rat bone. Figures reprinted from [135], with permission from Elsevier. A key is provided to help differentiate between different types of osteoporosis (idiopathic/general, senile, postmenopausal, and steroidinduced) and between human and animal (mainly mice or rats) samples. (b) Chemical changes: (i) Shifted bone mineral density distribution (BMDD) curves, indicating hypomineralization compared to healthy human bone. Figure is replotted using data from [136]. FTIR micro-spectroscopic images showing spatially resolved mineral (ii) crystallinity and (iii) mineral-to-matrix ratio, respectively, for healthy and osteoporotic patient bone. Figures reprinted from [41]. (c) Altered in situ deformation behavior in WT and ovariectomized mice using nanopillar samples: $(1,4)$ AFM images, $(2,5)$ SEM images, and $(3,6)$ TEM images of a crack. Figures reprinted from [130], with permission from the American Chemical Society.

While it remains unclear why fine structural features of osteoporotic bone can be different for different subtypes of the disease, what is evident is that such abnormalities will undermine bone mechanics at the relevant length scales. Determined using nanoindentation, the compressive elastic modulus of the (dry) tibial bone from a nanopillar specimen of an ovariectomized mouse decreased to 18.0 $\pm 2.2 \mathrm{GPa}$ from $27.9 \pm 1.7 \mathrm{GPa}$ in WT control [130]. On an ultrastructural level, a reduction in the fibrillar stiffness was measured [131,137], likely a result of shorter fibrils and lack of fibrillar alignment and organization degree in osteoporotic bone tissues. Additionally, the diminished mineral content in osteoporotic bone also contributes to decreased stiffness of mineralized fibrils [138]. A drop in elastic modulus also manifested itself under tensile testing on the tissue level [137], where the overall decreased amount of stress-concentrating bone mineral is likely the main contributor. Using correlative imaging-nanomechanical testing within an electron microscope, Wang et al. were one of the first to analyze the in-situ fracture behavior of osteoporotic bone, although the sample imaged was not in its near-native state since it was prepared following traditional protocols, with fixation, dehydration, and embedding in a resin. Fractographic images in Figure 4c indicate that the crack propagation front is narrower and sharper, giving rise to a confined deformation zone for ovariectomy-induced osteoporotic bone. From this, the microcrack deflection mechanism in healthy, tough bone can be assumed to be compromised in an osteoporotic disease state. In healthy bone, in situ imaging of micromechanical deformation suggests that the collagen fibrils become disarrayed locally around the crack tip, with significant fibrillar bridges [11]. In osteoporotic bone, both SEM and TEM images revealed the absence of fibril and/or ligament bridging (Figure 4c, middle and right). These could again be rationalized by the aforementioned abnormalities in the mineralized collagen fibrils in osteoporosis pathology, rendering the normal collagen-mediated strengthening and toughening mechanisms at the fibrillar level ineffective.

Despite decades of progress, the underlying ultrastructural anomalies in osteoporotic bones remain largely undefined. Osteopenia, which is characterized by significant bone loss before osteoporosis, does not necessarily lead to an osteoporotic state. Nevertheless, relevant genetically modified animal models do not typically differentiate between osteopenia and osteoporosis as they are phenotypically similar. Furthermore, additional work is needed to elucidate whether there are unique changes in the nanostructure and chemistry of bone associated with postmenopausal (ovariectomy-induced), steroid-, or glucocorticoid-induced versus senile osteoporosis, which would require ultrastructural imaging and analysis of the same features in multiple subtypes of osteoporotic samples. Complications arise when there are other underlying conditions as a large number of 
molecular, genetic, and environmental factors can contribute to osteoporosis pathogenesis $[139,140]$. Therefore, genetically engineered animal models might be more suited for decoupling the effects of these factors before pinpointing nanoscale changes in biopsy samples from osteoporotic patients. The perspectives offered in Section 2.3 on correlative imaging-nanomechanical testing are also applicable to study the in-situ deformation behavior of (hydrated) osteoporotic bone at the ultrastructural scale.

\subsection{Osteogenesis Imperfecta}

Osteogenesis imperfecta (OI), more commonly known as brittle bone disease, is a skeletal disease with a genetic origin, affecting one in 15,000 to 20,000 people at birth. It is a heterogeneous disease in that there are more than ten types of OI, some of which are yet to be clinically classified [141]. In almost all OI pathologies, the Type I collagen encoding genes COL1A1 and COL1A2 undergo autosomal mutations, giving rise to defective collagen in terms of its quality-including mutations in the amino acid sequence, over-modification of the collagen chain, and its protein folding-and quantity [141].

Because OI is a collagen-related disease, most studies have focused on the ultrastructural examination of OI-affected bone, especially the organic collagen phase. Osteogenesis imperfecta murine (OIM) models are widely used in the literature to mimic OI pathologies of varying severities, where homozygous oim/oim best recapitulate the characteristics of moderate-to-severe human OI and heterozygous $\mathrm{oim} /+$ recapitulate those of mild human OI [32,141-144]. For the mineral phase, smaller bone apatite crystal size and decreased crystal thickness were established in both human and mice models [142,143,145]. Moreover, the reduction in crystal thickness correlated well with OI severity, where the homozygous OI phenotype possessed a crystal thickness approximately $10 \%$ smaller compared to the heterozygous phenotype [145]. As in osteoporosis pathology, OI pathology led to a change in the aspect ratio and thus the morphology of the bone mineral at the nanoscale. Increased crystal misorientation was confirmed using SAXS, TEM imaging, and SAED pattern analysis $[32,142,143,146]$. By analyzing a large number of high-resolution TEM images, the angular distribution of the (intrafibrillar) crystal orientation for the OI sample (Figure 5(ai)) showed a spread that was twice as large as that of healthy bone [146], which corroborated similar quantitative comparison using SAED data [32]. It was also interesting to note that, through quantifying their distributions, the minerals were less misoriented in bone with spondyloepiphyseal dysplasia congenita, another pathology that is caused by defective collagen due to a mutation in the COL2A1 gene, than in bone with OI. This suggests that nanoscale changes to bone structure, whilst similar in qualitative terms, can be highly differential [146]. In terms of mineralization, there were incidences of localized patchy biomineralized clusters in Type II OI, the most lethal form of OI [147]. For the collagen phase, starting at the molecular scale, the trimeric tropocollagen can comprise a mix of normal and mutant $\alpha 1$ Type I chains in OI pathology [148]. Such molecular defects can then propagate to higher structural hierarchies. Indeed, fibril assemblies of tropocollagen were seen to have an altered morphology in OI patient bone [147]. Specifically, the collagen fibril diameter was reduced, and the diameter distribution appeared to be more variable based on TEM observation [147]. Cross-sectional TEM images also showed angular-like features of the collagen fibril edges, which can result in the loss of the typical quasi-hexagonal packing (Figure 5(aii)) [147]. Both patient (type III OI) and OIM samples showed that the collagen fibrils are less aligned with increased tortuosity and sparseness in its organization $[32,143,147,149]$. Using TEM, Eren et al. were also successful in directly visualizing structural disorders in the collagen in OI pathology [146]. However, disparate results on the effect of OI on the collagen banding pattern were recorded based on TEM image analysis: $\mathrm{D}$ banding periodicity remained constant, $\sim 65 \mathrm{~nm}$, in both WT and the OIM model [32], whereas this value was significantly reduced to $62 \mathrm{~nm}$ in a type IV OI specimen from an eight-year-old child [146]. 
a
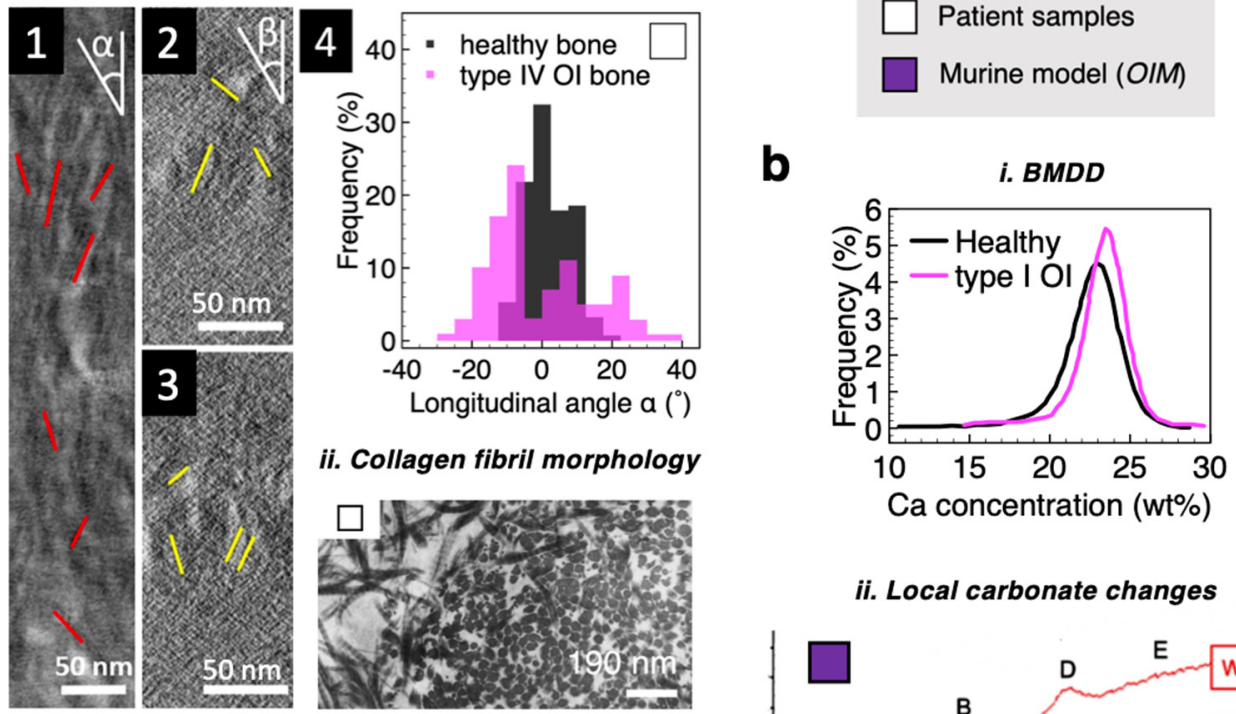

ii. Local carbonate changes
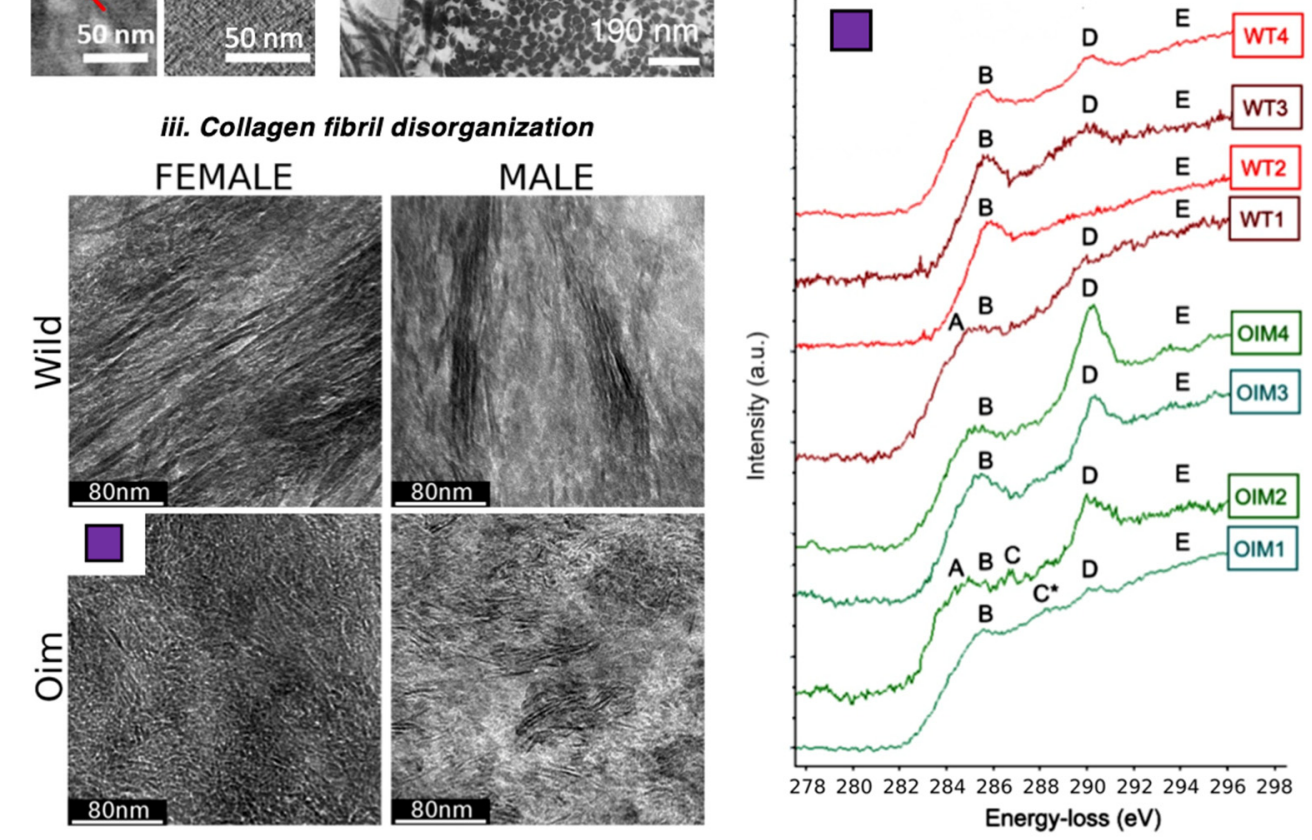

C
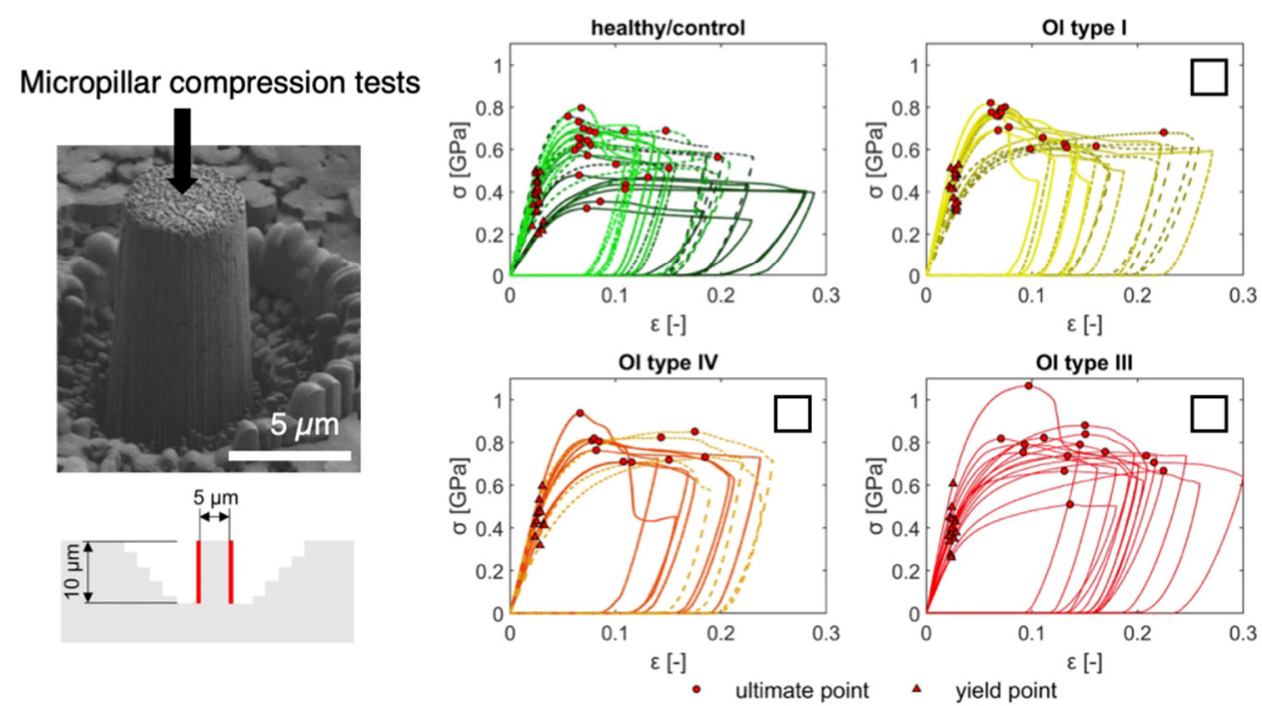

Figure 5. Altered bone structure, chemistry, and micromechanics in osteogenesis imperfecta (OI) pathology. (a) Ultrastructural changes: (i) TEM images showing (1) a single collagen fibril and (1-3) its intrafibrillar crystals in a type IV OI patient bone. The distribution of the longitudinal angle $\alpha$ of 
the crystals is plotted in (4). For reference, corresponding data for healthy bone from [150] are plotted. Figures reprinted from [146]. (ii) Altered fibril morphology in type III OI patient bone. Figure reprinted from [147], with permission from Wiley. (iii) TEM images comparing the collagen fibril organizations in WT and OIM bone. Figures reprinted from [32], with permission from the American Chemical Society. (b) Chemical changes: (i) Shifted bone mineral density distribution (BMDD) curves, indicating slight hypermineralization compared to healthy human bone. Figure is replotted using data from [136]. (ii) Nanoscale changes in the carbonate content of minerals in OIM bone. Spectra reprinted from [32], with permission from the American Chemical Society. For detailed spectral interpretation and peak assignment (labeled A-E), readers are referred to the original paper [32]. (c) Micromechanical properties of healthy vs. OI bone under compression using micropillar samples. Compressive strength of bone was found to increase with OI severity. Figures reprinted with permission from [46].

Chemical alterations in OI-affected bone also start at the nanoscale. Biochemically, dysregulation of NCP expressions is common in OI and varies with disease severity: with reduced levels of ON (SPARC) and increased BSP content [151]. As a result, NCP-collagen interactions become compromised in recessive OI. The bone minerals in OI pathology were less crystalline, and reductions in both the carbonate and phosphate contents have been recorded (Figure 5(bi)) [39,142,152]. However, these values were averaged across the entire specimen examined, and localized alterations could not be identified. Kłosowski et al. employed spatially-resolved STEM-EELS to probe the fine structures of carbon K and nitrogen $\mathrm{K}$ edges in the high-energy loss region of the spectrum, revealing nanoscale chemical changes in OIM bone tissue [32]. In Figure 5(bii), the peak-labeled D, with an energy loss of 290.0-290.2 eV, corresponds to the transitions of carbonate groups, and the shoulder $E$ is indicative of carbonate $1 \mathrm{~s} \rightarrow \sigma^{*}-C$ and $\pi^{*}-C$ transitions [32]. Using this spectral information, the authors identified highly heterogeneous distributions of carbonate-rich and carbonate-deficient regions in OI bone compared to WT control [32]. This alludes to a defective mineralization process, with a highly localized and spatially inhomogeneous molecular origin that calls for further examination. Overall, ultrastructural defects in both the mineral and collagen phases generally correlate well with the severity of the OI type [147].

Numerous studies have reported modified whole-bone-level mechanics of OI bone, including decreased compressive elastic modulus, reduced bending strength, increased compressive strength, increased hardness, and, most notably, heightened brittleness compared to healthy counterparts $[142,143,152,153]$. For smaller length scales, an increased compressive modulus was found in the extracellular matrix of OI bone compared to WT using FIB-machined micropillar samples, and the magnitude of increase appeared to correlate with the degree of bone mineralization and disease severity (Figure 5c) [46]. In another recent study, by subjecting OIM bone to ex-situ micropillar compression tests and through finite element modeling, Maghsoudi-Ganjeh et al. proposed the possible mechanical behavior of OI bone at the fibrillar level [153]. Under compressive stress, OIM bone was found to fail in a manner consistent with brittle materials: the machined bone micropillars cracked and underwent splitting in the longitudinal direction, whereas the WT control after mechanical failure displayed a shear failure plane with localized plastic deformation zones [153]. It was suggested that the misorientation of the mineral crystals, along with a lack of intrafibrillar mineralization, contribute to a compromised load transfer mechanism between the mineral and collagen phases of bone, leading to poor mechanical performance of the bone [153].

\subsection{Paget's Disease}

The hallmark of Paget's disease is excessive bone resorption followed by anomalous bone formation, resulting in deformities at the whole-bone level [154]. Genetic determinants of the disease include SQSTM1, which encodes a protein that partakes in the 
regulation of osteoclasts [154]. In the sclerotic phase of this multistage disease, where new bone formation exceeds resorption, there is a haphazard deposition of collagens, giving rise to what is known as a "mosaic pattern" of woven and lamellar bone [155]. Compared to osteoporosis or OI, relatively few studies have been dedicated to studying the ultrastructural characteristics and mechanics of bone with Paget's disease. Nevertheless, these recent results offer similar extents of insights into the pathological state of the affected bone. Paget's disease usually causes a reduction in the average mineralization of bone [156,157], and the BMDD also shifted to lower values with a broader distribution [157]. While the exact mineral dimensions and morphology remain elusive, spatially heterogeneous distribution in mineral orientation angles and disorganized mineral arrangement were confirmed using a combination of small-angle and wide-angle X-ray scattering techniques [158]. As for the collagen phase, the random orientation of the fibrils with more crosslinks was observed at the microstructural level, producing woven bone [157]. Ex-situ fracture mechanical testing of Paget's disease patient bone revealed a negligible change in the fracture toughness of the affected bone, yet significant different deformation mechanisms were inferred from the crack paths [157]. It was suggested that there was a balance between impaired bone quality and increased intrinsic toughening via ductile plastic deformation due to a higher collagen-to-mineral ratio $[157,159]$.

\subsection{Rickets and Osteomalacia}

Rickets and osteomalacia are two closely linked bone disorders, where the diseased bone is abnormally soft due to hypomineralized bone matrix. Because of this, the ultrastructural features of the collagen fibrils have been less studied compared to the mineral phase of bone in these pathological conditions. Both hypophosphatemia (i.e., having low concentrations of phosphate in the blood) and vitamin D deficiency can lead to rachitic and osteomalacic bone, yet these two causes can present different disease characteristics at the nanometric level.

Rickets arising from a deficiency in phosphates are called hypophosphatemic rickets, synonymous with X-linked hypophosphatemia (XLH) or vitamin-D-resistant rickets. In hypophosphatemic-rickets-affected bone, sometimes denoted Hyp bone, there is a decreased average degree of mineralization. Karunaratne et al. revealed that this incomplete mineralization was heterogeneous, detecting a $21 \%$ reduction in extrafibrillar mineralization but negligible changes in the intrafibrillar mineral content using qBEI [160]. Additionally, the distribution pattern of the bone mineral also appeared more variable compared to healthy WT bone [160]. During bone development, the mineralization process was found to have terminated prematurely in Hyp bone, where FIB-SEM images showed a greater amount of smaller mineral ellipsoids in the affected bone matrix [27]. These mineral ellipsoids were believed to mature into the cross-fibrillar minerals seen in healthy adult bone. As a result of this premature arrest in mineralization during bone growth, a greater variability in mineral size was measured and defective mineral packing and mineralization patterns were seen in the FIB-SEM images of hypophosphatemic-rickets-affected bone [27]. On a microstructural level, abnormal patchy mineralization of the collagen bundles was also captured using SEM [160]. The patchy appearance of the mineralized bone in hypophosphatemic rickets pathology likely resembles bone tissues with osteogenesis imperfecta or Paget's disease, mentioned previously, as well as in osteomalacia [161]. Since there was an overall decreased amount of high-stiffness bone mineral, a significant $70 \%$ reduction in fibril-level stiffness-i.e., a softening of bone-was measured under both tension and compression $[160,162]$. As such, a common nanostructural mechanism becomes evident: both lower stiffness and greater fibril extensibility are observed in hypomineralized collagen of bone at the fibrillar level. This also holds true for osteoporotic bone [137].

In the rickets or osteomalacia-like disease phenotype induced by severe vitamin $\mathrm{D}$ deficiency, the BMDD shifts to higher Ca values, reminiscent of aged bone tissue [119]. This is different from bone with hypophosphatemic rickets with a hypomineralized bone matrix. 
Specifically, the osteocyte lacunae in vitamin-D-deficient bone were hypermineralized [119]. It is thus apparent that in both hypophosphatemic and vitamin-D deficiency-induced rickets, the changes in bone mineralization proved to be spatially heterogeneous. Bone from individuals with vitamin $\mathrm{D}$ deficiencies also presented decreased fracture toughness. In situ fracture testing of hydrated WT and diseased bone in an ESEM showed that the deformation pathways during fracture were dissimilar and that there was an absence of normal toughening mechanisms in bone with vitamin-D deficiency [119].

\section{Treating Bone Diseases: Evidence from Bone Imaging and Analysis}

\subsection{Pharmaceutical Drugs}

Common pharmacological interventions for bone diseases, especially osteoporosis, include bisphosphonates and strontium ranelate. Bisphosphonates encompass a number of pharmaceutical drugs such as alendronate (sold under the trade names Fosamax, Binosto), risedronate (Atelvia, Actonel), and zoledronate (Reclast). Nitrogen-containing bisphosphonates are particularly preferred for treating Paget's disease of the bone [163]. As an inhibitor of osteoclast activity, bisphosphonates minimize bone resorption and suppress bone turnover. While they can indeed stabilize bone loss in osteoporotic and OI patients, improve BMD, and decrease porosity $[136,164]$, there are systemic drug-induced side effects such as severe musculoskeletal pain or stroke. One well-known long-term complication of bisphosphonate use is osteonecrosis, particularly in the jaw [48]. Moreover, defects in the ultrastructure of diseased bone can either remain undealt with or emerge unintentionally following bisphosphonate treatments. There is evidence that bisphosphonates such as tiludronate can improve bone mineralization to a level similar to healthy bone [165]. However, the bisphosphonate-induced mineralization can be uncontrolled and heterogeneous in nature [166]. Moreover, ovariectomized osteoporotic rats treated with tiludronate showed a significant $\sim 30 \%$ increase in crystal thickness, at dosing concentrations of both 35 and $160 \mathrm{mg} \mathrm{kg}^{-1}$, despite that no initial difference was observed in crystal thickness between sham and osteoporotic bone [165]. Similar studies have shown that different bisphosphonates can indeed induce different morphological changes in apatite nanocrystallites [167]. Effects of bisphosphonate treatment on collagen at the molecular and fibrillar levels remain to be further investigated, likely leaving the disorganized collagenous matrix unaltered. These ultrastructural defects can lead to even more compromised mechanical performance of the bone, including reduced fracture toughness when compared to the untreated pathological state $[49,168]$.

Approved by the European Medicines Agency, strontium ranelate is another antiresorptive drug. In vitro investigations have demonstrated that strontium ranelate promotes osteoblast differentiation and proliferation whilst inhibiting osteoclastic activities, promoting new bone formation $[169,170]$. Improvements on the whole-bone level included increased bone mass and micro-architecture [171]. At the nanoscale, apatite minerals of bone remained relatively unchanged with respect to crystal thickness, morphology, orientation, and mineral crystallinity [172,173]. Divalent strontium ions $\mathrm{Sr}^{2+}$, with a high binding affinity for hydroxyapatite, were believed to incorporate into the crystal lattice of the neo-bone, only affecting the lattice parameters and carbonate substitutions in the apatite mineral [173-175]. Regarding the collagen phase, no apparent improvements were seen in the arrangement and organization of the collagen fibers when examining, using TEM, the bones of ovariectomized osteoporotic rats following strontium ranelate treatment [176]. Rat bone strength improved significantly compared to the untreated conditions but not to the level of healthy controls [176]. On the other hand, the toughness of bone did not ameliorate even compared to the untreated osteoporotic bone [176]. For patient specimens, the nanomechanical properties of bone, including compressive modulus and hardness, showed no apparent improvements [175]. Despite their extensive clinical use, both bisphosphonates and strontium ranelate fail to address the nanoscale defects in pathological bone. There thus exists a need for alternative treatment options, precisely targeting ultrastructural changes such as defective collagen structure whilst minimizing adverse side effects. 


\subsection{Cell and Gene Therapy}

Many pathological conditions of bone are genetic in origin, with intrinsic molecularlevel defects or cellular-level damage such as defective collagen in OI pathology or illregulated osteoblasts in Paget's disease. Therefore, cell and gene therapies are better suited to correct these skeletal disorders. Cell and gene therapy relies on the change or introduction of genetic material that resides in the cell nucleus: cell therapy is via blood transfusion of ex-vivo modified cells, whereas gene therapy typically operates through targeted delivery for in vivo modification of the genetic material of the patient. To treat OI pathology, bone marrow stem cells were transplanted into OIM mice or children [177-179]. Both $\alpha 1$ and $\alpha 2$ type I collagens were correctly expressed following cell engraftment. There was a partial recovery in bone quality, where increased bone mineralization density and improved homogeneity and, thus, better organization in mineral distribution were observed [178]. Notably, nanoindentation and the macroscale four-point bending test revealed mitigation of the severe brittleness of OI bone, with some mechanical properties being similar to those of healthy WT bone $[177,178]$. For in vivo gene therapy, an ovariectomized osteoporotic mouse showed improved micro-architecture and reduced bone loss following the transfer of the human interleukin-1 receptor antagonist gene [180].

Hypophosphatasia (HPP), a metabolic disorder of bone, is caused by mutations in the ALPL gene and is linked to a deficiency in the NCP tissue-nonspecific alkaline phosphatase, or TNAP. As a result of TNAP- $\mathrm{D}_{10}$ administration, treated mice with infantile HPP showed improved survival and extended lifespan [181]. There were also few signs of rickets-like bone deformities in the mice treated with this virus-mediated gene therapy, and the resulting bone shared many microstructural similarities to normal WT bone [181]. Similar attempts were also made for other pathologies, including osteogenesis imperfecta or osteoarthritis [182-184]. Since application-based studies in this area remain scarce, collagen-mineral ultrastructural examination of the treated bone is largely absent in the literature at this stage. One other limiting factor is that the efficacy of many of these treatments has not reached observable macroscopic phenotypes that resemble healthy WTs, rendering high-resolution imaging non-essential. Studies tend to focus exclusively on biological and biochemical analyses and visualization using histomorphometry. Despite this, nanoscale imaging and analysis can still offer appreciable information, including the identification of favorable (and possibly localized) changes in the mineral or collagenous ultrastructure of the treated bone and the determination of whether the newly produced collagen can self-assemble into the correct organization.

\subsection{Materials Science and Tissue Engineering Approaches}

Currently, almost all bone biomaterials studied/developed have only had their potential demonstrated in vitro or have been exclusively for repairing fracture or necrosisinduced defect(s). Discussed below are possible candidates to address bone pathologies.

In autosomal dominant OI, gene defects in COL1A1 result in reduced collagen content [141]. Ceria nanoparticles may be a promising candidate to tackle this. Nanoceria/bioglass nanocomposite scaffolds can increase collagen production in vivo from human mesenchymal stem cells seeded onto the scaffold and promote their differentiation into osteoblasts [185]. More work is needed to examine the quality of the collagen produced as well as the collagen texture in neo-bone using appropriate in vivo models. Nanoceria with a mixture of $3+$ and $4+$ oxidation states have antioxidant and radical-scavenging capabilities, as evidenced by an in vitro study involving a co-culture of osteoblasts and macrophages [186]. Nanoceria used in osteoporosis treatment could neutralize the overproduction of reactive oxygen species in age-related osteoporosis pathology [139] and could promote osteogenesis. Additionally, nanoceria-loaded mesoporous silica nanoparticles have the advantage that they can be internalized by cells but cannot enter the nucleus, thus avoiding any unintended genetic modification [186].

On the other end of the spectrum, patients with severely deformed bones or with pathological fractures would require revision surgeries, and bone implants are needed. For 
instance, for patients suffering from Paget's disease of the bone and skeletal deformities, total hip or knee replacement and internal fixation for pathological fractures are common surgical measures [187]. Following removal of the malformed bone, either metal/alloy fixations or tissue-engineered bone scaffolds are to be implanted. Tissue-engineered bone scaffolds are becoming increasingly investigated, with a surge in the number of new or modified designs over the last few years. Biomimetic tissue-engineered scaffolds can act as an internal fixation measure to support patient mobility, provided that there is satisfactory osseointegration and good mechanical performance of the scaffold to enable effective load transfer to host bone. Porous strontium-containing bioglass scaffolds, as a composite material, leverage the therapeutic effects of both $\mathrm{Sr}^{2+}$ ions and bioactive glass [188]. In an in vivo animal study, the Sr-loading led to enhanced and more rapid osseointegration compared to bioglass alone. In particular, the fibril organization of collagen improved drastically. The fibrils assemble in parallel layers to the lamellar bone in a strontiumcontaining bioglass scaffold, whereas the bioglass-only scaffold resulted in randomly oriented collagen bundles and irregularly shaped lacunae [188]. Of note, bone matrix NCPs can be incorporated into bone scaffolds through direct covalent incorporation into polymeric chains that make up the polymer-based scaffold via chemical modification of the implant surface or as soluble biologics that become loaded into the porous scaffold [61]. The incorporation of or modification with NCPs not only enables better mimicking of the microenvironment of the extracellular matrix of bone but also leverages the therapeutic potential of certain NCPs.

When these bone biomaterials become implanted into the body at the pathological or defect site, ultrastructural imaging and nanoscale analysis can be used to examine the extent of repair mediated by these biomaterials and the organization of mineralized collagen around the implant [189]. Nanometric information against treatment time can be obtained to investigate the efficiency of bone repair if samples are sourced periodically following biomaterial implantation. Nanoscale imaging and analysis can be highly informative and can even become integrated into understanding the efficacy of new gene and cell therapies, pharmaceutical drugs, and bone bio-nanomaterials for treating bone disorders.

\section{Perspectives on Studying Pathological and Treated Bone at the Nanoscale}

Understanding bone pathologies at the nanoscale requires high-resolution imaging and nanoanalytical techniques. In an ideal scenario, samples should not undergo any harsh preparation protocol in order to retain their native physiological state. When investigating the fracture mechanism of diseased bone, the majority imaged the bone samples before and after mechanical testing, or ex situ, to infer the deformation mechanisms. Some employed scattering techniques to help monitor in situ strain at the fibril level without the ability to directly visualize the deformation processes [162]. For direct imaging, the bone samples were typically in dry conditions due to the high-vacuum environment of the traditional EM sample holder. Therefore, it is difficult to directly correlate the role of water with its structure and mechanical features at the micron scale or below. In-situ deformation behavior of pathological bone during fracture thus remains largely unexplored, rendering the establishment of structure-mechanical properties of diseased bone tissue difficult. Additionally, through reviewing the literature on current bone repair strategies, there is also a paucity of evidence on mineral-collagen ultrastructural changes in treated bone. These present fertile grounds for further research. Figure 6 schematically illustrates some research perspectives in understanding bone pathologies, also applicable to treated bone, starting at the nanoscale: these areas are broadly classified into "what to test", "how to test", and "what to characterize". 

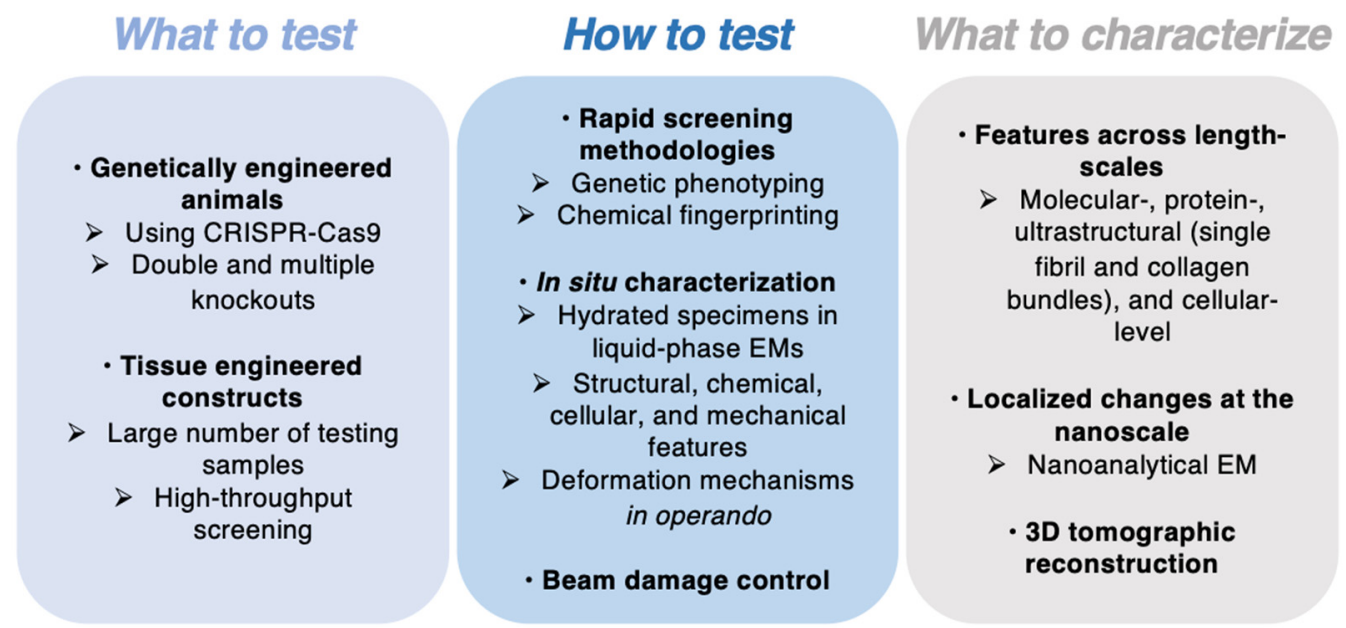

Figure 6. Challenges and opportunities for studying pathological and treated bone.

Discussions in both Sections 2 and 3 illustrate the useful employment of genetically engineered mice to model human skeletal diseases. To reiterate, single- and doubleknockout mice models were generated to study the effects of specific bone matrix NCP deficiencies on bone structure, chemistry, and mechanics (Table 2), and these have been successful in capturing some disease phenotypes. However, double-knockout models remain less investigated, and multiple knockouts, which might prove useful in modeling SLRP-deficiency-related pathologies, are essentially non-existent. At the same time, knockin models were also used to generate, for example, OIM models to simulate human osteogenesis imperfecta pathology of varying severities. Since both the roles of NCPs in bone and some bone pathologies are still not fully unraveled, there is a need to continue studying artificial models of human diseases. Compared to methods commonly reported in the current literature on modeling bone diseases (e.g., cross-breeding), novel technologies such as CRISPR-Cas9 for genome editing can offer much more rapid model generation with high-precision, as recently illustrated for type V OI in mice [190]. Besides genetically modified animal models, tissue-engineered (TE) constructs have recently emerged as a new, less-animal-cruel, physiologically-mimetic alternative to model human diseases in different tissues. In animal models, a large number of animals are likely to be sacrificed for experimental testing before even moving onto clinical trials, making the use of TE constructs more attractive in terms of sustainability. Furthermore, these in vivo animal models are often too complex to allow the isolation of single factors that could be the (dominant) causative origin of a disease. Iordachescu et al. have designed an in vitro bone model derived from human primary cells or immortalized cell line populations, which can provide a deeper understanding of the development of bone and has been used in a pilot study to identify new compounds that block ossification [191]. This model consists of a simple self-structuring structure generated by human cells from a fibrin gel cast and calcium phosphate ceramic anchors, where ordered mineralized collagen fibrils are deposited and remodeled over time, up to one year [191]. Such TE composite scaffolds provide a reliable platform for evaluating the efficacies of bone biomaterials and drugs. Using a large number of TE constructs, the high-throughput screening of therapeutics that can potentially restore the organization and thus mechanics of pathological bone tissues is possible.

In Section 2.3, we have offered some perspectives on in situ examination of bone properties. However, these detailed analyses will prove time-consuming when trying to identify "hits" or macroscopically apparent changes in disease phenotypes. Therefore, we propose that high-throughput screening methodologies should be employed prior to detailed nanoscale imaging to streamline sample analysis. Examples include phenotypic screening, such as that based on gene expressions, as well as transcutaneous vibrational imaging of bone without the need for additional sample preparation to identify key chemi- 
cal differences between healthy and pathological bone [39,192]. The use of TE constructs instead of animal models for human diseases also facilitates the initial rapid screening. Subsequently, on samples of particular interest, in situ EM imaging and chemical and micromechanical testing can be performed. One possibility for multimodal analysis is that micro- or nanopillar bone specimens used in ESEM imaging and in situ micromechanical testing can be sliced and transferred to a static liquid-cell TEM where the sample slice is hermetically sealed within an aqueous envelope for further analysis in a not only hydrated but also physiologically relevant aqueous environment [123]. The electron-beam-induced damage can also be minimized using specially designed liquid cell membranes, such as multilayer graphene or other 2D nanomaterials, in liquid-cell electron microscopy [123]. More importantly, to understand the deformation behavior of pathological bone tissues, in situ imaging and mechanical testing must be performed at the length scales pertinent to the hierarchical strengthening and toughening mechanisms of bone [8].

In terms of "what to characterize", while in this review, we have paid exclusive attention to the ultrastructural level features of pathological bone, other length scales are also pivotal in understanding the attributes of pathological and treated bone. Chemical changes at the molecular level should be considered. An example of this is using nanoanalytical electron microscopy such as STEM-EELS to understand localized chemical alterations in morbid bone, such as pathological mineralization [14,32]. This also highlights the need to monitor localized changes in diseased bone instead of using an averaged measure to describe the already heterogeneous and anisotropic bone properties. At the level of proteins, which are also nanoscale in size (usually sub-10 nm), NCPs play key roles in the structure and mechanics of the bone matrix as well as the entire tissue assembly. Electron microscopy imaging can enable the ultrastructural localization of proteins within the bone's hierarchy, as evidenced by a recent high-resolution TEM study [62]. Simon et al. located OC on collagen fibrils and in a mineral crystal structure in human trabecular bone. Then, one can compare the structural characteristics at the same length scale in OC-deficient bone and subsequently pinpoint at what length scale the transfer of structural information becomes significantly aberrant. The data collected are likely 2D images, but 3D spatial information is usually desired as they may provide a different and truer perspective than static $2 \mathrm{D}$ images $[10,146]$. Therefore, serial imaging and 3D tomographic reconstruction should be sought when possible. For many bone pathologies such as Paget's disease, the cellular machineries of osteoblasts and osteoclasts are impaired. Studies dating back to more than 20-30 years ago have extensively surveyed the ultrastructure of bone cells in pathological conditions, examining the structural changes in membrane-bound organelles $[147,156]$. Yet, considering how much bone bioimaging has advanced in the past few decades with the emergence of novel imaging techniques (such as correlative light electron microscopy, CLEM) as well as new knowledge about bone and bone cells, fresh insights and more systematic investigations are needed. One question might be: how is the process of mineralization mediated by intracellular phosphate-containing vesicles altered in diseased bone (such as in OC-OPN double-deficient mice), and how would this be implicated in the mineralization pattern and its extent in bone [15]?

Finally, there appears to be incomplete quantitative analysis of the SEM or S/TEM images in the literature, even in recent reports. For example, whilst many have mapped and quantified the misorientation angle of mineral nanocrystallites in the bone matrix, few have reported the same for disorganized and misaligned collagen fibrils, common in many bone pathologies. Possible metrics include distribution of the fibril length; quantitative changes to the D banding, gap zone, and overlap zone of collagen; and mapping of the misorientation angle of the fibril assemblies. Quantification of these altered ultrastructural details can be helpful for comparison between healthy and diseased bone, between different pathological states, or even for correlation with mechanical properties (e.g., bone toughness as a function of the degree of fibril misalignment). 


\section{Conclusions}

Nanoscale imaging coupled with chemical and mechanical analysis is crucial to help understand: (1) the ultrastructural and chemical characteristics of bone in a variety of pathologies, (2) the deformation mechanism of diseased bones, and (3) the success of bone repair strategies. This review examined existing studies on the ultrastructural imaging of bone tissues in their pathological states, correlating to their compromised mechanical performance where appropriate. The structure-property relationship of bone begins at the molecular scale. Non-collagenous bone matrix proteins are a vital part of bone, performing both structural and physiological functions. Deficiencies of NCPs lead to changes in bone at the ultrastructural level and are associated with numerous bone diseases, as documented by single- or double-animal knockout studies. In examining individual bone diseases, from osteoporosis to osteomalacia, there are limited yet insightful results on their tissue properties at the nanoscale. Common to many pathological states are nanoscale changes in both the mineral and collagen phases of bone, including disorganized collagen fibril assemblies and abnormal mineralization patterns. The ultrastructure, chemistry, and nanomechanics of pathological bones are seldomly studied together, and, for this reason, both NCP-deficient bone and models of a variety of skeletal diseases deserve further exploration before we can have a firm grasp of the pathological changes in patient biopsy samples in clinical settings. Relevant to the discussion of bone pathologies are ways to treat pathological bone conditions, where we have discussed current pharmaceutical treatments and summarized approaches specifically targeting molecular- or nanoscale-level defects in diseased tissues. Novel treatments targeting defective collagen structure, organization, and/or abnormal mineralization patterns are highly desired. With advanced imaging and analytical techniques (e.g., nanoanalytical EM), attributes of bone at the nanoscale can be resolved and elucidated in the context of pathological tissues and repaired bone.

Author Contributions: Conceptualization and review outline: V.G.-G., Z.H., F.G. and A.E.P.; Writingoriginal draft preparation: V.G.-G. and Z.H.; Writing—review and editing: V.G.-G., Z.H., F.G. and A.E.P.; Supervision: F.G. and A.E.P.; Funding acquisition: A.E.P. All authors have read and agreed to the published version of the manuscript.

Funding: This research was funded by a grant from the Engineering and Physical Sciences Research Council (EPSRC; grant number EP/S023259/1) to the EPSRC and SFI Centre for Doctoral Training in the Advanced Characterisation of Materials (CDT-ACM).

Institutional Review Board Statement: Not applicable.

Informed Consent Statement: Not applicable.

Data Availability Statement: Not applicable.

Conflicts of Interest: The authors declare no conflict of interest. The funders had no role in the design of the study; in the collection, analyses, or interpretation of data; in the writing of the manuscript, or in the decision to publish the results.

\section{References}

1. Wu, A.-M.; Bisignano, C.; James, S.L.; Abady, G.G.; Abedi, A.; Abu-Gharbieh, E.; Alhassan, R.K.; Alipour, V.; Arabloo, J.; Asaad, M.; et al. Global, Regional, and National Burden of Bone Fractures in 204 Countries and Territories, 1990-2019: A Systematic Analysis from the Global Burden of Disease Study 2019. Lancet Health Longev. 2021, 2, e580-e592. [CrossRef]

2. Compston, J.E.; McClung, M.R.; Leslie, W.D. Osteoporosis. Lancet 2019, 393, 364-376. [CrossRef]

3. Sozen, T.; Ozisik, L.; Basaran, N.C. An Overview and Management of Osteoporosis. Eur. J. Rheumatol. 2017, 4, 46-56. [CrossRef]

4. Forlino, A.; Marini, J.C. Osteogenesis Imperfecta. Lancet 2016, 387, 1657-1671. [CrossRef]

5. Granke, M.; Does, M.D.; Nyman, J.S. The Role of Water Compartments in the Material Properties of Cortical Bone. Calcif. Tissue Int. 2015, 97, 292-307. [CrossRef] [PubMed]

6. Launey, M.E.; Buehler, M.J.; Ritchie, R.O. On the Mechanistic Origins of Toughness in Bone. Annu. Rev. Mater. Res. 2010, 40, 25-53. [CrossRef]

7. Hernandez, C.J.; Keaveny, T.M. A Biomechanical Perspective on Bone Quality. Bone 2006, 39, 1173-1181. [CrossRef] [PubMed]

8. Zimmermann, E.A.; Ritchie, R.O. Bone as a Structural Material. Adv. Healthc. Mater. 2015, 4, 1287-1304. [CrossRef] [PubMed] 
9. Morgan, S.; Poundarik, A.A.; Vashishth, D. Do Non-Collagenous Proteins Affect Skeletal Mechanical Properties? Calcif. Tissue Int. 2015, 97, 281-291. [CrossRef] [PubMed]

10. Reznikov, N.; Bilton, M.; Lari, L.; Stevens, M.M.; Kröger, R. Fractal-like Hierarchical Organization of Bone Begins at the Nanoscale. Science 2018, 360, eaao2189. [CrossRef] [PubMed]

11. Aldegaither, N.; Sernicola, G.; Mesgarnejad, A.; Karma, A.; Balint, D.; Wang, J.; Saiz, E.; Shefelbine, S.J.; Porter, A.E.; Giuliani, F. Fracture Toughness of Bone at the Microscale. Acta Biomater. 2021, 121, 475-483. [CrossRef] [PubMed]

12. Orgel, J.P.R.O.; Irving, T.C.; Miller, A.; Wess, T.J. Microfibrillar Structure of Type I Collagen in Situ. Proc. Natl. Acad. Sci. USA 2006, 103, 9001-9005. [CrossRef]

13. Schwarcz, H.P.; McNally, E.A.; Botton, G.A. Dark-Field Transmission Electron Microscopy of Cortical Bone Reveals Details of Extrafibrillar Crystals. J. Struct. Biol. 2014, 188, 240-248. [CrossRef] [PubMed]

14. Nitiputri, K.; Ramasse, Q.M.; Autefage, H.; McGilvery, C.M.; Boonrungsiman, S.; Evans, N.D.; Stevens, M.M.; Porter, A.E. Nanoanalytical Electron Microscopy Reveals a Sequential Mineralization Process Involving Carbonate-Containing Amorphous Precursors. ACS Nano 2016, 10, 6826-6835. [CrossRef]

15. Boonrungsiman, S.; Gentleman, E.; Carzaniga, R.; Evans, N.D.; McComb, D.W.; Porter, A.E.; Stevens, M.M. The Role of Intracellular Calcium Phosphate in Osteoblast-Mediated Bone Apatite Formation. Proc. Natl. Acad. Sci. USA 2012, 109, 14170-14175. [CrossRef] [PubMed]

16. Jantou-Morris, V.; Horton, M.A.; McComb, D.W. The Nano-Morphological Relationships between Apatite Crystals and Collagen Fibrils in Ivory Dentine. Biomaterials 2010, 31, 5275-5286. [CrossRef] [PubMed]

17. Tertuliano, O.A.; Greer, J.R. The Nanocomposite Nature of Bone Drives Its Strength and Damage Resistance. Nat. Mater. 2016, 15, 1195-1202. [CrossRef] [PubMed]

18. Mahamid, J.; Sharir, A.; Gur, D.; Zelzer, E.; Addadi, L.; Weiner, S. Bone Mineralization Proceeds through Intracellular Calcium Phosphate Loaded Vesicles: A Cryo-Electron Microscopy Study. J. Struct. Biol. 2011, 174, 527-535. [CrossRef]

19. Quan, B.D.; Sone, E.D. Cryo-TEM Analysis of Collagen Fibrillar Structure, 1st ed.; Elsevier Inc.: Amsterdam, The Netherlands, 2013; Volume 532. [CrossRef]

20. Erickson, B.; Fang, M.; Wallace, J.M.; Orr, B.G.; Les, C.M.; Holl, M.M.B. Nanoscale Structure of Type I Collagen Fibrils: Quantitative Measurement of D-Spacing. Biotechnol. J. 2013, 8, 117-126. [CrossRef]

21. Jones, M.G.; Andriotis, O.G.; Roberts, J.J.W.; Lunn, K.; Tear, V.J.; Cao, L.; Ask, K.; Smart, D.E.; Bonfanti, A.; Johnson, P.; et al. Nanoscale Dysregulation of Collagen Structure-Function Disrupts Mechano-Homeostasis and Mediates Pulmonary Fibrosis. Elife 2018, 7, e36354. [CrossRef] [PubMed]

22. Skedros, J.G.; Holmes, J.L.; Vajda, E.G.; Bloebaum, R.D. Cement Lines of Secondary Osteons in Human Bone Are Not MineralDeficient: New Data in a Historical Perspective. Anat. Rec.-Part A Discov. Mol. Cell. Evol. Biol. 2005, 286, 781-803. [CrossRef] [PubMed]

23. Feng, J.Q.; Ward, L.M.; Liu, S.; Lu, Y.; Xie, Y.; Yuan, B.; Yu, X.; Rauch, F.; Davis, S.I.; Zhang, S.; et al. Loss of DMP1 Causes Rickets and Osteomalacia and Identifies a Role for Osteocytes in Mineral Metabolism. Nat. Genet. 2006, 38, 1310-1315. [CrossRef]

24. Boyde, A. Improved Digital SEM of Cancellous Bone: Scanning Direction of Detection, through Focus for in-Focus and Sample Orientation. J. Anat. 2003, 202, 183-194. [CrossRef]

25. Bereshiem, A.C.; Pfeiffer, S.K.; Grynpas, M.D.; Alblas, A. Use of Backscattered Scanning Electron Microscopy to Quantify the Bone Tissues of Midthoracic Human Ribs. Am. J. Phys. Anthropol. 2019, 168, 262-278. [CrossRef] [PubMed]

26. Sato, C.; Yamazaki, D.; Sato, M.; Takeshima, H.; Memtily, N.; Hatano, Y.; Tsukuba, T.; Sakai, E. Calcium Phosphate Mineralization in Bone Tissues Directly Observed in Aqueous Liquid by Atmospheric SEM (ASEM) without Staining: Microfluidics Crystallization Chamber and Immuno-EM. Sci. Rep. 2019, 9, 7352. [CrossRef] [PubMed]

27. Buss, D.J.; Reznikov, N.; McKee, M.D. Crossfibrillar Mineral Tessellation in Normal and Hyp Mouse Bone as Revealed by 3D FIB-SEM Microscopy. J. Struct. Biol. 2020, 212, 107603. [CrossRef] [PubMed]

28. Raguin, E.; Rechav, K.; Shahar, R.; Weiner, S. Focused Ion Beam-SEM 3D Analysis of Mineralized Osteonal Bone: Lamellae and Cement Sheath Structures. Acta Biomater. 2021, 121, 497-513. [CrossRef] [PubMed]

29. Binkley, D.M.; Deering, J.; Yuan, H.; Gourrier, A.; Grandfield, K. Ellipsoidal Mesoscale Mineralization Pattern in Human Cortical Bone Revealed in 3D by Plasma Focused Ion Beam Serial Sectioning. J. Struct. Biol. 2020, 212, 107615. [CrossRef]

30. Bromage, T.G.; Goldman, H.M.; McFarlin, S.C.; Warshaw, J.; Boyde, A.; Riggs, C.M. Circularly Polarized Light Standards for Investigations of Collagen Fiber Orientation in Bone. Anat. Rec.-Part B New Anat. 2003, 274, 157-168. [CrossRef]

31. Georgiadis, M.; Guizar-Sicairos, M.; Gschwend, O.; Hangartner, P.; Bunk, O.; Möller, R.; Schneider, P. Ultrastructure Organization of Human Trabeculae Assessed by 3D SSAXS and Relation to Bone Microarchitecture. PLoS ONE 2016, 11, e0159838. [CrossRef] [PubMed]

32. Kłosowski, M.M.; Carzaniga, R.; Abellan, P.; Ramasse, Q.; McComb, D.W.; Porter, A.E.; Shefelbine, S.J. Electron Microscopy Reveals Structural and Chemical Changes at the Nanometer Scale in the Osteogenesis Imperfecta Murine Pathology. ACS Biomater. Sci. Eng. 2017, 3, 2788-2797. [CrossRef] [PubMed]

33. Kłosowski, M.M.; Friederichs, R.J.; Nichol, R.; Antolin, N.; Carzaniga, R.; Windl, W.; Best, S.M.; Shefelbine, S.J.; McComb, D.W.; Porter, A.E. Probing Carbonate in Bone Forming Minerals on the Nanometre Scale. Acta Biomater. 2015, 20, 129-139. [CrossRef] [PubMed] 
34. Alexander, B.; Daulton, T.L.; Genin, G.M.; Lipner, J.; Pasteris, J.D.; Wopenka, B.; Thomopoulos, S. The Nanometre-Scale Physiology of Bone: Steric Modelling and Scanning Transmission Electron Microscopy of Collagen-Mineral Structure. J. R. Soc. Interface 2012, 9, 1774-1786. [CrossRef] [PubMed]

35. Bloebaum, R.D.; Skedros, J.G.; Vajda, E.G.; Bachus, K.N.; Constantz, B.R. Determining Mineral Content Variations in Bone Using Backscattered Electron Imaging. Bone 1997, 20, 485-490. [CrossRef]

36. Depalle, B.; McGilvery, C.M.; Nobakhti, S.; Aldegaither, N.; Shefelbine, S.J.; Porter, A.E. Osteopontin Regulates Type I Collagen Fibril Formation in Bone Tissue. Acta Biomater. 2021, 120, 194-202. [CrossRef] [PubMed]

37. Gamsjaeger, S.; Mendelsohn, R.; Boskey, A.L.; Gourion-Arsiquaud, S.; Klaushofer, K.; Paschalis, E.P. Vibrational Spectroscopic Imaging for the Evaluation of Matrix and Mineral Chemistry. Curr. Osteoporos. Rep. 2014, 12, 454-464. [CrossRef]

38. Mandair, G.S.; Morris, M.D. Contributions of Raman Spectroscopy to the Understanding of Bone Strength. Bonekey Rep. 2015, 4, 620. [CrossRef] [PubMed]

39. Draper, E.R.C.; Morris, M.D.; Camacho, N.P.; Matousek, P.; Towrie, M.; Parker, A.W.; Goodship, A.E. Novel Assessment of Bone Using Time-Resolved Transcutaneous Raman Spectroscopy. J. Bone Miner. Res. 2005, 20, 1968-1972. [CrossRef]

40. Miller, L.M.; Vairavamurthy, V.; Chance, M.R.; Mendelsohn, R.; Paschalis, E.P.; Betts, F.; Boskey, A.L. In Situ Analysis of Mineral Content and Crystallinity in Bone Using Infrared Micro-Spectroscopy of the $\mathrm{N}_{4} \mathrm{PO}_{4}{ }^{3-}$ Vibration. Biochim. Biophys. Acta-Gen. Subj. 2001, 1527, 11-19. [CrossRef]

41. Boskey, A.; Mendelsohn, R. Infrared Analysis of Bone in Health and Disease. J. Biomed. Opt. 2005, 10, 031102. [CrossRef]

42. Saito, M.; Marumo, K. Collagen Cross-Links as a Determinant of Bone Quality: A Possible Explanation for Bone Fragility in Aging, Osteoporosis, and Diabetes Mellitus. Osteoporos. Int. 2010, 21, 195-214. [CrossRef] [PubMed]

43. Langelier, B.; Wang, X.; Grandfield, K. Atomic Scale Chemical Tomography of Human Bone. Sci. Rep. 2017, 7, 39958. [CrossRef] [PubMed]

44. Henss, A.; Rohnke, M.; El Khassawna, T.; Govindarajan, P.; Schlewitz, G.; Heiss, C.; Janek, J. Applicability of ToF-SIMS for Monitoring Compositional Changes in Bone in a Long-Term Animal Model. J. R. Soc. Interface 2013, 10, 20130332. [CrossRef]

45. Jimenez-Palomar, I.; Shipov, A.; Shahar, R.; Barber, A.H. Mechanical Behavior of Osteoporotic Bone at Sub-Lamellar Length Scales. Front. Mater. 2015, 2, 9. [CrossRef]

46. Indermaur, M.; Casari, D.; Kochetkova, T.; Peruzzi, C.; Zimmermann, E.; Rauch, F.; Willie, B.; Michler, J.; Schwiedrzik, J.; Zysset, P. Compressive Strength of Iliac Bone ECM Is Not Reduced in Osteogenesis Imperfecta and Increases with Mineralization. J. Bone Miner. Res. 2021, 36, 1364-1375. [CrossRef] [PubMed]

47. Schwiedrzik, J.; Raghavan, R.; Bürki, A.; Lenader, V.; Wolfram, U.; Michler, J.; Zysset, P. In Situ Micropillar Compression Reveals Superior Strength and Ductility but an Absence of Damage in Lamellar Bone. Nat. Mater. 2014, 13, 740-747. [CrossRef] [PubMed]

48. Migliorati, C.A.; Siegel, M.A.; Elting, L.S. Bisphosphonate-Associated Osteonecrosis: A Long-Term Complication of Bisphosphonate Treatment. Lancet Oncol. 2006, 7, 508-514. [CrossRef]

49. Lloyd, A.A.; Gludovatz, B.; Riedel, C.; Luengo, E.A.; Saiyed, R.; Marty, E.; Lorich, D.G.; Lane, J.M.; Ritchie, R.O.; Busse, B.; et al Atypical Fracture with Long-Term Bisphosphonate Therapy Is Associated with Altered Cortical Composition and Reduced Fracture Resistance. Proc. Natl. Acad. Sci. USA 2017, 114, 8722-8727. [CrossRef]

50. Georgiadis, M.; Mu, R.; Schneider, P. Techniques to Assess Bone Ultrastructure Organization: Orientation and Arrangement of Mineralized Collagen Fibrils. J. R. Soc. Interface 2016, 13, 20160088. [CrossRef] [PubMed]

51. Binkley, D.M.; Grandfield, K. Advances in Multiscale Characterization Techniques of Bone and Biomaterials Interfaces. ACS Biomater. Sci. Eng. 2018, 4, 3678-3690. [CrossRef]

52. Shah, F.A.; Ruscsák, K.; Palmquist, A. 50 Years of Scanning Electron Microscopy of Bone-A Comprehensive Overview of the Important Discoveries Made and Insights Gained into Bone Material Properties in Health, Disease, and Taphonomy. Bone Res. 2019, 7, 15. [CrossRef] [PubMed]

53. Nikel, O.; Laurencin, D.; McCallum, S.A.; Gundberg, C.M.; Vashishth, D. NMR Investigation of the Role of Osteocalcin and Osteopontin at the Organic-Inorganic Interface in Bone. Langmuir 2013, 29, 13873-13882. [CrossRef] [PubMed]

54. Tesch, W.; Vandenbos, T.; Roschgr, P.; Fratzl-Zelman, N.; Klaushofer, K.; Beertsen, W.; Fratzl, P. Orientation of Mineral Crystallites and Mineral Density during Skeletal Development in Mice Deficient in Tissue Nonspecific Alkaline Phosphatase. J. Bone Miner. Res. 2003, 18, 117-125. [CrossRef] [PubMed]

55. Horiuchi, K.; Amizuka, N.; Takeshita, S.; Takamatsu, H.; Katsuura, M.; Ozawa, H.; Toyama, Y.; Bonewald, L.F.; Kudo, A. Identification and Characterization of a Novel Protein, Periostin, with Restricted Expression to Periosteum and Periodontal Ligament and Increased Expression by Transforming Growth Factor $\beta$. J. Bone Miner. Res. 1999, 14, 1239-1249. [CrossRef] [PubMed]

56. Sroga, E.; Vashishth, D.; Sroga, G.E.; Vashishth, D. Effects of Bone Matrix Proteins on Fracture and Fragility in Osteoporosis. Curr. Osteoporos. Rep. 2012, 10, 141-150. [CrossRef]

57. Licini, C.; Vitale-Brovarone, C.; Mattioli-Belmonte, M. Collagen and Non-Collagenous Proteins Molecular Crosstalk in the Pathophysiology of Osteoporosis. Cytokine Growth Factor Rev. 2019, 49, 59-69. [CrossRef]

58. Berendsen, A.D.; Pinnow, E.L.; Maeda, A.; Brown, A.C.; McCartney-Francis, N.; Kram, V.; Owens, R.T.; Robey, P.G.; Holmbeck, K.; de Castro, L.F.; et al. Biglycan Modulates Angiogenesis and Bone Formation during Fracture Healing. Matrix Biol. 2014, 35 , 223-231. [CrossRef] 
59. Malaval, L.; Monfoulet, L.; Fabre, T.; Pothuaud, L.; Bareille, R.; Miraux, S.; Thiaudiere, E.; Raffard, G.; Franconi, J.M.; LafageProust, M.H.; et al. Absence of Bone Sialoprotein (BSP) Impairs Cortical Defect Repair in Mouse Long Bone. Bone 2009, 45, 853-861. [CrossRef]

60. Poundarik, A.A.; Diab, T.; Sroga, G.E.; Ural, A.; Boskey, A.L.; Gundberg, C.M.; Vashishth, D. Dilatational Band Formation in Bone. Proc. Natl. Acad. Sci. USA 2012, 109, 19178-19183. [CrossRef]

61. Carvalho, M.S.; Cabral, J.M.S.S.; da Silva, C.L.; Vashishth, D. Bone Matrix Non-Collagenous Proteins in Tissue Engineering: Creating New Bone by Mimicking the Extracellular Matrix. Polymers 2021, 13, 1095. [CrossRef]

62. Simon, P.; Grüner, D.; Worch, H.; Pompe, W.; Lichte, H.; El Khassawna, T.; Heiss, C.; Wenisch, S.; Kniep, R. First Evidence of Octacalcium Phosphate@osteocalcin Nanocomplex as Skeletal Bone Component Directing Collagen Triple-Helix Nanofibril Mineralization. Sci. Rep. 2018, 8, 13696. [CrossRef]

63. Fantner, G.E.; Adams, J.; Turner, P.; Thurner, P.J.; Fisher, L.W.; Hansma, P.K. Nanoscale Ion Mediated Networks in Bone: Osteopontin Can Repeatedly Dissipate Large Amounts of Energy. Nano Lett. 2007, 7, 2491-2498. [CrossRef] [PubMed]

64. Boskey, A.L.; Villarreal-Ramirez, E. Intrinsically Disordered Proteins and Biomineralization. Matrix Biol. 2016, 52-54, 43-59. [CrossRef]

65. Poundarik, A.A.; Boskey, A.; Gundberg, C.; Vashishth, D. Biomolecular Regulation, Composition and Nanoarchitecture of Bone Mineral. Sci. Rep. 2018, 8, 1191. [CrossRef] [PubMed]

66. Boskey, A.L. Noncollagenous Matrix Proteins and Their Role in Mineralization. Bone Miner. 1989, 6, 111-123. [CrossRef]

67. Termine, J.D.; Kleinman, H.K.; Whitson, S.W.; Conn, K.M.; McGarvey, M.L.; Martin, G.R. Osteonectin, a Bone-Specific Protein Linking Mineral to Collagen. Cell 1981, 26, 99-105. [CrossRef]

68. Gorski, J.P.; Hankenson, K.D. Secreted Noncollagenous Proteins of Bone; Elsevier Inc.: Amsterdam, The Netherlands, 2019. [CrossRef]

69. Fantner, G.E.; Hassenkam, T.; Kindt, J.H.; Weaver, J.C.; Birkedal, H.; Pechenik, L.; Cutroni, J.A.; Cidade, G.A.G.; Stucky, G.D.; Morse, D.E.; et al. Sacrificial Bonds and Hidden Length Dissipate Energy as Mineralized Fibrils Separate during Bone Fracture. Nat. Mater. 2005, 4, 612-616. [CrossRef]

70. Wang, Y.; Morsali, R.; Dai, Z.; Minary-Jolandan, M.; Qian, D. Computational Nanomechanics of Noncollagenous Interfibrillar Interface in Bone. ACS Appl. Mater. Interfaces 2020, 12, 25363-25373. [CrossRef]

71. Bedell, M.A.; Largaespada, D.A.; Jenkins, N.A.; Copeland, N.G. Mouse Models of Human Disease. Part II: Recent Progress and Future Directions. Genes Dev. 1997, 11, 11-43. [CrossRef] [PubMed]

72. Bailey, S.; Karsenty, G.; Gundberg, C.; Vashishth, D. Osteocalcin and Osteopontin Influence Bone Morphology and Mechanical Properties. Ann. N. Y. Acad. Sci. 2017, 1049, 79-84. [CrossRef]

73. Bouleftour, W.; Juignet, L.; Verdière, L.; Machuca-Gayet, I.; Thomas, M.; Laroche, N.; Vanden-Bossche, A.; Farlay, D.; Thomas, C.; Gineyts, E.; et al. Deletion of OPN in BSP Knockout Mice Does Not Correct Bone Hypomineralization but Results in High Bone Turnover. Bone 2019, 120, 411-422. [CrossRef]

74. Corsi, A.; Xu, T.; Chen, X.D.; Boyde, A.; Liang, J.; Mankani, M.; Sommer, B.; Iozzo, R.V.; Eichstetter, I.; Robey, P.G.; et al. Phenotypic Effects of Biglycan Deficiency Are Linked to Collagen Fibril Abnormalities, Are Synergized by Decorin Deficiency, and Mimic Ehlers-Danlos-like Changes in Bone and Other Connective Tissues. J. Bone Miner. Res. 2002, 17, 1180-1189. [CrossRef] [PubMed]

75. Wadhwa, S.; Bi, Y.; Ortiz, A.T.; Embree, M.C.; Kilts, T.; Iozzo, R.; Opperman, L.A.; Young, M.F. Impaired Posterior Frontal Sutural Fusion in the Biglycan/Decorin Double Deficient Mice. Bone 2007, 40, 861-866. [CrossRef] [PubMed]

76. Nuka, S.; Zhou, W.; Henry, S.P.; Gendron, C.M.; Schultz, J.B.; Shinomura, T.; Johnson, J.; Behringer, R.R.; Young, M.F.; Ho, M.; et al. Phenotypic Characterization of Epiphycan-Deficient and Epiphycan/Biglycan Double-Deficient Mice 1. Osteoarthr. Cartil. 2010, 18, 88-96. [CrossRef]

77. Hessle, L.; Johnson, K.A.; Anderson, H.C.; Narisawa, S.; Sali, A.; Goding, J.W.; Terkeltaub, R.; Millán, J.L. Tissue-Nonspecific Alkaline Phosphatase and Plasma Cell Membrane Glycoprotein-1 Are Central Antagonistic Regulators of Bone Mineralization. Proc. Natl. Acad. Sci. USA 2002, 99, 9445-9449. [CrossRef] [PubMed]

78. Anderson, H.C.; Harmey, D.; Camacho, N.P.; Garimella, R.; Sipe, J.B.; Tague, S.; Bi, X.; Johnson, K.; Terkeltaub, R.; Millán, J.L. Sustained Osteomalacia of Long Bones despite Major Improvement in Other Hypophosphatasia-Related Mineral Deficits in Tissue Nonspecific Alkaline Phosphatase/Nucleotide Pyrophosphatase Phosphodiesterase 1 Double-Deficient Mice. Am. J. Pathol. 2005, 166, 1711-1720. [CrossRef]

79. Malaval, L.; Wade-Guéye, N.M.; Boudiffa, M.; Fei, J.; Zirngibl, R.; Chen, F.; Laroche, N.; Roux, J.P.; Burt-Pichat, B.; Duboeuf, F.; et al. Bone Sialoprotein Plays a Functional Role in Bone Formation and Osteoclastogenesis. J. Exp. Med. 2008, 205, 1145-1153. [CrossRef] [PubMed]

80. Ameye, L.; Young, M.F. Mice Deficient in Small Leucine-Rich Proteoglycans: Novel in Vivo Models for Osteoporosis, Osteoarthritis, Ehlers-Danlos Syndrome, Muscular Dystrophy, and Corneal Diseases. Glycobiology 2002, 12, 107-116. [CrossRef] [PubMed]

81. Thurner, P.J.; Chen, C.G.; Ionova-Martin, S.; Sun, L.; Harman, A.; Porter, A.; Ager, J.W.; Ritchie, R.O.; Alliston, T. Osteopontin Deficiency Increases Bone Fragility but Preserves Bone Mass. Bone 2010, 46, 1564-1573. [CrossRef] [PubMed]

82. Duvall, C.L.; Taylor, W.R.; Weiss, D.; Wojtowicz, A.M.; Guldberg, R.E. Impaired Angiogenesis, Early Callus Formation, and Late Stage Remodeling in Fracture Healing of Osteopontin-Deficient Mice. J. Bone Miner. Res. 2007, 22, 286-297. [CrossRef]

83. Chang, I.C.; Chiang, T.I.; Yeh, K.T.; Lee, H.; Cheng, Y.W. Increased Serum Osteopontin Is a Risk Factor for Osteoporosis in Menopausal Women. Osteoporos. Int. 2010, 21, 1401-1409. [CrossRef] 
84. Matsui, Y.; Iwasaki, N.; Kon, S.; Takahashi, D.; Morimoto, J.; Matsui, Y.; Denhardt, D.T.; Rittling, S.; Minami, A.; Uede, T. Accelerated Development of Aging-Associated and Instability-Induced Osteoarthritis in Osteopontin-Deficient Mice. Arthritis Rheum. 2009, 60, 2362-2371. [CrossRef]

85. Ducy, P.; Desbois, C.; Boyce, B.; Pinero, G.; Story, B.; Dunstan, C.; Smith, E.; Bonadio, J.; Goldstein, S.; Gundberg, C.; et al. Increased Bone Formation in Osteocalcin-Deficient Mice. Nature 1996, 382, 448-452. [CrossRef] [PubMed]

86. Berezovska, O.; Yildirim, G.; Budell, W.C.; Yagerman, S.; Pidhaynyy, B.; Bastien, C.; van der Meulen, M.C.H.; Dowd, T.L. Osteocalcin Affects Bone Mineral and Mechanical Properties in Female Mice. Bone 2019, 128, 115031. [CrossRef] [PubMed]

87. Boskey, A.L.; Gadaleta, S.; Gundberg, C.; Doty, S.B.; Ducy, P.; Karsenty, G. Fourier Transform Infrared Microspectroscopic Analysis of Bones of Osteocalcin-Deficient Mice Provides Insight into the Function of Osteocalcin. Bone 1998, 23, 187-196. [CrossRef]

88. Kavukcuoglu, N.B.; Patterson-Buckendahl, P.; Mann, A.B. Effect of Osteocalcin Deficiency on the Nanomechanics and Chemistry of Mouse Bones. J. Mech. Behav. Biomed. Mater. 2009, 2, 348-354. [CrossRef]

89. Raymond, M.H.; Schutte, B.C.; Torner, J.C.; Burns, T.L.; Willing, M.C. Osteocalcin: Genetic and Physical Mapping of the Human Gene BGLAP and Its Potential Role in Postmenopausal Osteoporosis. Genomics 1999, 60, 210-217. [CrossRef]

90. Delany, A.M.; Amling, M.; Priemel, M.; Howe, C.; Baron, R.; Canalis, E. Osteopenia and Decreased Bone Formation in OsteonectinDeficient Mice. J. Clin. Investig. 2000, 105, 915-923. [CrossRef] [PubMed]

91. Mansergh, F.C.; Wells, T.; Elford, C.; Evans, S.L.; Perry, M.J.; Evans, M.J.; Evans, B.A.J. Osteopenia in Sparc (Osteonectin)-Deficient Mice: Characterization of Phenotypic Determinants of Femoral Strength and Changes in Gene Expression. Physiol. Genom. 2007, 32, 64-73. [CrossRef]

92. Boskey, A.L.; Moore, D.J.; Amling, M.; Canalis, E.; Delany, A.M. Infrared Analysis of the Mineral and Matrix in Bones of Osteonectin-Null Mice and Their Wildtype Controls. J. Bone Miner. Res. 2003, 18, 1005-1011. [CrossRef] [PubMed]

93. Delany, A.M.; McMahon, D.J.; Powell, J.S.; Greenberg, D.A.; Kurland, E.S. Osteonectin/SPARC Polymorphisms in Caucasian Men with Idiopathic Osteoporosis. Osteoporos. Int. 2008, 19, 969-978. [CrossRef]

94. Mendoza-Londono, R.; Fahiminiya, S.; Majewski, J.; Tétreault, M.; Nadaf, J.; Kannu, P.; Sochett, E.; Howard, A.; Stimec, J.; Dupuis, L.; et al. Recessive Osteogenesis Imperfecta Caused by Missense Mutations in SPARC. Am. J. Hum. Genet. 2015, 96, 979-985. [CrossRef] [PubMed]

95. Wallace, J.M.; Golcuk, K.; Morris, M.D.; Kohn, D.H.; Cbl, B.; Mice, C.H.H.; Wallace, J.M.; Golcuk, K.; Morris, M.D.; Kohn, D.H. Inbred Strain-Specific Response to Biglycan Deficiency in the Cortical Bone of C57BL6/129 and C3H/He Mice. J. Bone Miner. Res. 2009, 24, 1002-1012. [CrossRef] [PubMed]

96. Wallace, J.M.; Rajachar, R.M.; Chen, X.D.; Shi, S.; Allen, M.R.; Bloomfield, S.A.; Les, C.M.; Robey, P.G.; Young, M.F.; Kohn, D.H. The Mechanical Phenotype of Biglycan-Deficient Mice Is Bone- and Gender-Specific. Bone 2006, 39, 106-116. [CrossRef] [PubMed]

97. Xu, T.; Bianco, P.; Fisher, L.W.; Longenecker, G.; Smith, E.; Goldstein, S.; Bonadio, J.; Boskey, A.; Heegaard, A.M.; Sommer, B.; et al. Targeted Disruption of the Biglycan Gene Leads to an Osteoporosis-like Phenotype in Mice. Nat. Genet. 1998, 20 , 78-82. [CrossRef] [PubMed]

98. Hua, R.; Ni, Q.; Eliason, T.D.; Han, Y.; Gu, S.; Nicolella, D.P.; Wang, X.; Jiang, J.X. Biglycan and Chondroitin Sulfate Play Pivotal Roles in Bone Toughness via Retaining Bound Water in Bone Mineral Matrix. Matrix Biol. 2020, 94, 95-109. [CrossRef]

99. Chen, X.D.; Shi, S.; Xu, T.; Robey, P.G.; Young, M.F. Age-Related Osteoporosis in Biglycan-Deficient Mice Is Related to Defects in Bone Marrow Stromal Cells. J. Bone Miner. Res. 2002, 17, 331-340. [CrossRef] [PubMed]

100. Bonnet, N.; Standley, K.N.; Bianchi, E.N.; Stadelmann, V.; Foti, M.; Conway, S.J.; Ferrari, S.L. The Matricellular Protein Periostin Is Required for Sost Inhibition and the Anabolic Response to Mechanical Loading and Physical Activity. J. Biol. Chem. 2009, 284, 35939-35950. [CrossRef] [PubMed]

101. Gerbaix, M.; Vico, L.; Ferrari, S.L.; Bonnet, N. Periostin Expression Contributes to Cortical Bone Loss during Unloading. Bone 2015, 71, 94-100. [CrossRef] [PubMed]

102. Attur, M.; Duan, X.; Cai, L.; Han, T.; Zhang, W.; Tycksen, E.D.; Samuels, J.; Brophy, R.H.; Abramson, S.B.; Rai, M.F. Periostin Loss-of-Function Protects Mice from Post-Traumatic and Age-Related Osteoarthritis. Arthritis Res. 2021, 23, 1-14. [CrossRef] [PubMed]

103. Bonnet, N.; Gineyts, E.; Ammann, P.; Conway, S.J.; Garnero, P.; Ferrari, S. Periostin Deficiency Increases Bone Damage and Impairs Injury Response to Fatigue Loading in Adult Mice. PLoS ONE 2013, 8, e78347. [CrossRef]

104. Hu, F.; Shang, X.F.; Wang, W.; Jiang, W.; Fang, C.; Tan, D.; Zhou, H.C. High-Level Expression of Periostin Is Significantly Correlated with Tumour Angiogenesis and Poor Prognosis in Osteosarcoma. Int. J. Exp. Pathol. 2016, 97, 86-92. [CrossRef] [PubMed]

105. Anderson, H.C.; Sipe, J.B.; Hessle, L.; Dhamyamraju, R.; Atti, E.; Camacho, N.P.; Millán, J.L. Impaired Calcification Around Matrix Vesicles of Growth Plate and Bone in Alkaline Phosphatase-Deficient Mice. Am. J. Pathol. 2004, 164, 841-847. [CrossRef]

106. Fedde, K.N.; Blair, L.; Silverstein, J.; Coburn, S.P.; Ryan, L.M.; Weinstein, R.S.; Waymire, K.; Narisawa, S.; Millán, J.L.; MacGregor, G.R.; et al. Alkaline Phosphatase Knock-out Mice Recapitulate the Metabolic and Skeletal Defects of Infantile Hypophosphatasia. J. Bone Miner. Res. 1999, 14, 2015-2026. [CrossRef] [PubMed]

107. Whyte, M.P.; Greenberg, C.R.; Salman, N.J.; Bober, M.B.; McAlister, W.H.; Wenkert, D.; Van Sickle, B.J.; Simmons, J.H.; Edgar, T.S.; Bauer, M.L.; et al. Enzyme-Replacement Therapy in Life-Threatening Hypophosphatasia. N. Engl. J. Med. 2012, 366, 904-913. [CrossRef] [PubMed]

108. Millán, J.L.; Whyte, M.P. Alkaline Phosphatase and Hypophosphatasia. Calcif. Tissue Int. 2016, 98, 398-416. [CrossRef] [PubMed] 
109. Ling, Y.; Rios, H.F.; Myers, E.R.; Lu, Y.; Feng, J.Q.; Boskey, A.L. DMP1 Depletion Decreases Bone Mineralization in Vivo: An FTIR Imaging Analysis. J. Bone Miner. Res. 2005, 20, 2169-2177. [CrossRef]

110. Zhang, Q.; Lin, S.; Liu, Y.; Yuan, B.; Harris, S.E.; Feng, J.Q. Dmp1 Null Mice Develop a Unique Osteoarthritis-like Phenotype. Int. J. Biol. Sci. 2016, 12, 1203-1212. [CrossRef]

111. Nielsen, K.L.; Allen, M.R.; Bloomfield, S.A.; Andersen, T.L.; Chen, X.D.; Poulsen, H.S.; Young, M.F.; Heegaard, A.M. Biglycan Deficiency Interferes with Ovariectomy-Induced Bone Loss. J. Bone Miner. Res. 2003, 18, 2152-2158. [CrossRef] [PubMed]

112. Edelman, G.M.; Gally, J.A. Degeneracy and Complexity in Biological Systems. Proc. Natl. Acad. Sci. USA 2001, 98, 13763-13768. [CrossRef]

113. Krishnan, P.; Hocking, A.M.; Scholtz, J.M.; Pace, C.N.; Holik, K.K.; McQuillan, D.J. Distinct Secondary Structures of the Leucine-Rich Repeat Proteoglycans Decorin and Biglycan. J. Biol. Chem. 1999, 274, 10945-10950. [CrossRef] [PubMed]

114. Dyne, K.M.; Valli, M.; Forlino, A.; Mottes, M.; Kresse, H.; Cetta, G. Deficient Expression of the Small Proteoglycan Decorin in a Case of Severe/Lethal Osteogenesis Imperfecta. Am. J. Med. Genet. 1996, 63, 161-166. [CrossRef]

115. Young, M.F.; Bi, Y.; Ameye, L.; Chen, X.D. Biglycan Knockout Mice: New Models for Musculoskeletal Diseases. Glycoconj. J. 2002, 19, 257-262. [CrossRef] [PubMed]

116. Moriishi, T.; Komori, T. Lack of Reproducibility in Osteocalcin-Deficient Mice. PLoS Genet. 2020, 16, e1008939. [CrossRef]

117. Wallace, J.M.; Golcuk, K.; Morris, M.D.; Kohn, D.H. Inbred Strain-Specific Effects of Exercise in Wild Type and Biglycan Deficient Mice. Ann. Biomed. Eng. 2010, 38, 1607-1617. [CrossRef]

118. Rodriguez-Florez, N.; Oyen, M.L.; Shefelbine, S.J. Insight into Differences in Nanoindentation Properties of Bone. J. Mech. Behav. Biomed. Mater. 2013, 18, 90-99. [CrossRef] [PubMed]

119. Busse, B.; Bale, H.A.; Zimmermann, E.A.; Panganiban, B.; Barth, H.D.; Carriero, A.; Vettorazzi, E.; Zustin, J.; Hahn, M.; Iii, J.W.A.; et al. Vitamin D Deficiency Induces Early Signs of Aging in Human Bone, Increasing the Risk of Fracture. Sci. Transl. Med. 2013, 5, 193ra88. [CrossRef]

120. Samuel, J.; Sinha, D.; Zhao, J.C.G.; Wang, X. Water Residing in Small Ultrastructural Spaces Plays a Critical Role in the Mechanical Behavior of Bone. Bone 2014, 59, 199-206. [CrossRef]

121. Koester, K.J.; Ager, J.W.; Ritchie, R.O. The True Toughness of Human Cortical Bone Measured with Realistically Short Cracks. Nat. Mater. 2008, 7, 672-677. [CrossRef] [PubMed]

122. Sakai, E.; Sato, M.; Memtily, N.; Tsukuba, T.; Sato, C. Liquid-Phase ASEM Imaging of Cellular and Structural Details in Cartilage and Bone Formed during Endochondral Ossification: Keap1-Deficient Osteomalacia. Sci. Rep. 2021, 11, 5722. [CrossRef]

123. Han, Z.; Porter, A.E. In Situ Electron Microscopy of Complex Biological and Nanoscale Systems: Challenges and Opportunities. Front. Nanotechnol. 2020, 2, 20. [CrossRef]

124. Ebenstein, D.M.; Pruitt, L.A. Nanoindentation of Biological Materials. Nano Today 2006, 1, 26-33. [CrossRef]

125. Schwiedrzik, J.; Taylor, A.; Casari, D.; Wolfram, U.; Zysset, P.; Michler, J. Nanoscale Deformation Mechanisms and Yield Properties of Hydrated Bone Extracellular Matrix. Acta Biomater. 2017, 60, 302-314. [CrossRef] [PubMed]

126. Casari, D.; Michler, J.; Zysset, P.; Schwiedrzik, J. Microtensile Properties and Failure Mechanisms of Cortical Bone at the Lamellar Level. Acta Biomater. 2021, 120, 135-145. [CrossRef]

127. Hawkins, F.; Garla, V.; Allo, G.; Males, D.; Mola, L.; Corpas, E. Senile and Postmenopausal Osteoporosis: Pathophysiology, Diagnosis, and Treatment; Elsevier Inc.: Amsterdam, The Netherlands, 2021. [CrossRef]

128. Rubin, M.A.; Jasiuk, I.; Taylor, J.; Rubin, J.; Ganey, T.; Apkarian, R.P. TEM Analysis of the Nanostructure of Normal and Osteoporotic Human Trabecular Bone. Bone 2003, 33, 270-282. [CrossRef]

129. Xi, L.; Zhang, Y.; Gupta, H.; Terrill, N.; Wang, P.; Zhao, T.; Fang, D. A Multiscale Study of Structural and Compositional Changes in a Natural Nanocomposite: Osteoporotic Bone with Chronic Endogenous Steroid Excess. Bone 2021, 143, 115666. [CrossRef]

130. Wang, Y.T.; Chang, S.Y.; Huang, Y.C.; Tsai, T.C.; Chen, C.M.; Lim, C.T. Nanomechanics Insights into the Performance of Healthy and Osteoporotic Bones. Nano Lett. 2013, 13, 5247-5254. [CrossRef]

131. Xi, L.; De Falco, P.; Barbieri, E.; Karunaratne, A.; Bentley, L.; Esapa, C.T.; Terrill, N.J.; Brown, S.D.M.M.; Cox, R.D.; Davis, G.R.; et al. Bone Matrix Development in Steroid-Induced Osteoporosis Is Associated with a Consistently Reduced Fibrillar Stiffness Linked to Altered Bone Mineral Quality. Acta Biomater. 2018, 76, 295-307. [CrossRef] [PubMed]

132. Mann, V.; Hobson, E.E.; Li, B.; Stewart, T.L.; Grant, S.F.A.; Robins, S.P.; Aspden, R.M.; Ralston, S.H. A COL1A1 Sp1 Binding Site Polymorphism Predisposes to Osteoporotic Fracture by Affecting Bone Density and Quality. J. Clin. Investig. 2001, 107, 899-907. [CrossRef]

133. Tokutomi, K.; Matsuura, T.; Atsawasuwan, P.; Sato, H.; Yamauchi, M. Characterization of Mandibular Bones in Senile Osteoporotic Mice. Connect. Tissue Res. 2008, 49, 361-366. [CrossRef] [PubMed]

134. Depalle, B.; Duarte, A.G.; Fiedler, I.A.K.; Pujo-Menjouet, L.; Buehler, M.J.; Berteau, J.P. The Different Distribution of Enzymatic Collagen Cross-Links Found in Adult and Children Bone Result in Different Mechanical Behavior of Collagen. Bone 2018, 110, 107-114. [CrossRef] [PubMed]

135. Kafantari, H.; Kounadi, E.; Fatouros, M.; Milonakis, M.; Tzaphlidou, M. Structural Alterations in Rat Skin and Bone Collagen Fibrils Induced by Ovariectomy. Bone 2000, 26, 349-353. [CrossRef]

136. Roschger, P.; Paschalis, E.P.; Fratzl, P.; Klaushofer, K. Bone Mineralization Density Distribution in Health and Disease. Bone 2008, 42, 456-466. [CrossRef] [PubMed] 
137. Karunaratne, A.; Xi, L.; Bentley, L.; Sykes, D.; Boyde, A.; Esapa, C.T.; Terrill, N.J.; Brown, S.D.M.; Cox, R.D.; Thakker, R.V.; et al. Multiscale Alterations in Bone Matrix Quality Increased Fragility in Steroid Induced Osteoporosis. Bone 2016, 84, 15-24. [CrossRef] [PubMed]

138. Chatzipanagis, K.; Baumann, C.G.; Sandri, M.; Sprio, S.; Tampieri, A.; Kröger, R. In Situ Mechanical and Molecular Investigations of Collagen/Apatite Biomimetic Composites Combining Raman Spectroscopy and Stress-Strain Analysis. Acta Biomater. 2016, 46, 278-285. [CrossRef] [PubMed]

139. Hendrickx, G.; Boudin, E.; Van Hul, W. A Look behind the Scenes: The Risk and Pathogenesis of Primary Osteoporosis. Nat. Rev. Rheumatol. 2015, 11, 462-474. [CrossRef]

140. Morris, J.A.; Kemp, J.P.; Youlten, S.E.; Laurent, L.; Logan, J.G.; Chai, R.C.; Vulpescu, N.A.; Forgetta, V.; Kleinman, A.; Mohanty, S.T.; et al. An Atlas of Genetic Influences on Osteoporosis in Humans and Mice. Nat. Genet. 2019, 51, 258-266. [CrossRef]

141. Forlino, A.; Cabral, W.A.; Barnes, A.M.; Marini, J.C. New Perspectives on Osteogenesis Imperfecta. Nat. Rev. Endocrinol. 2011, 7, 540-557. [CrossRef]

142. Grabner, B.; Landis, W.J.; Roschger, P.; Rinnerthaler, S.; Peterlik, H.; Klaushofer, K.; Fratzl, P. Age- and Genotype-Dependence of Bone Material Properties in the Osteogenesis Imperfecta Murine Model (Oim). Bone 2001, 29, 453-457. [CrossRef]

143. Vanleene, M.; Porter, A.; Guillot, P.V.; Boyde, A.; Oyen, M.; Shefelbine, S. Ultra-Structural Defects Cause Low Bone Matrix Stiffness despite High Mineralization in Osteogenesis Imperfecta Mice. Bone 2012, 50, 1317-1323. [CrossRef]

144. Masci, M.; Wang, M.; Imbert, L.; Barnes, A.M.; Spevak, L.; Lukashova, L.; Huang, Y.; Ma, Y.; Marini, J.C.; Jacobsen, C.M.; et al. Bone Mineral Properties in Growing Col1a2+/G610C Mice, an Animal Model of Osteogenesis Imperfecta. Bone 2016, 87, 120-129. [CrossRef]

145. Fratzl, P.; Paris, O.; Klaushofer, K.; Landis, W.J. Bone Mineralization in an Osteogenesis Imperfecta Mouse Model Studied by Small-Angle X-ray Scattering. J. Clin. Investig. 1996, 97, 396-402. [CrossRef] [PubMed]

146. Eren, E.D.; Nijhuis, W.H.; van der Weel, F.; Eren, A.D.; Ansari, S.; Bomans, P.H.H.; Friedrich, H.; Sakkers, R.J.; Weinans, H.; de With, G. Multiscale Characterization of Pathological Bone Tissue. Microsc. Res. Tech. 2021, 1-18. [CrossRef] [PubMed]

147. Sarathchandra, P.; Pope, F.M.; Kayser, M.V.; Ali, S.Y. A Light and Electron Microscopic Study of Osteogenesis Imperfecta Bone Samples, with Reference to Collagen Chemistry and Clinical Phenotype. J. Pathol. 2000, 192, 385-395. [CrossRef]

148. Gautieri, A.; Vesentini, S.; Redaelli, A.; Buehler, M.J. Single Molecule Effects of Osteogenesis Imperfecta Mutations in Tropocollagen Protein Domains. Protein Sci. 2009, 18, 161-168. [CrossRef] [PubMed]

149. Nadiarnykh, O.; Plotnikov, S.; Mohler, W.A.; Kalajzic, I.; Redford-Badwal, D.; Campagnola, P.J. Second Harmonic Generation Imaging Microscopy Studies of Osteogenesis Imperfecta. J. Biomed. Opt. 2007, 12, 051805. [CrossRef] [PubMed]

150. Xu, Y.F.; Nudelman, F.; Eren, E.D.; Wirix, M.J.M.; Cantaert, B.; Nijhuis, W.H.; Hermida-Merino, D.; Portale, G.; Bomans, P.H.H.; Ottmann, C.; et al. Intermolecular Channels Direct Crystal Orientation in Mineralized Collagen. Nat. Commun. 2020, 11, 5068. [CrossRef]

151. Vetter, U.; Fisher, L.W.; Mintz, K.P.; Kopp, J.B.; Tuross, N.; Termine, J.D.; Robey, P.G. Osteogenesis Imperfecta: Changes in Noncollagenous Proteins in Bone. J. Bone Miner. Res. 1991, 6, 501-505. [CrossRef]

152. Plumeyer, C.; Milovanovic, P.; Fiedler, I.A.K.; Schmidt, F.N.; Eva, M.W.; Gioia, R.; Tonelli, F.; Bale, H.A.; Katharina, J.; Besio, R.; et al. Severely Impaired Bone Material Quality in Chihuahua Zebra Fi Sh Resembles Classical Dominant Human Osteogenesis Imperfecta. J. Bone Miner. Res. 2018, 33, 1489-1499. [CrossRef]

153. Maghsoudi-Ganjeh, M.; Samuel, J.; Ahsan, A.S.; Wang, X.; Zeng, X. Intrafibrillar Mineralization Deficiency and Osteogenesis Imperfecta Mouse Bone Fragility. J. Mech. Behav. Biomed. Mater. 2021, 117, 104377. [CrossRef]

154. Singer, F.R. Paget's Disease of Bone-Genetic and Environmental Factors. Nat. Rev. Endocrinol. 2015, 11, 662-671. [CrossRef] [PubMed]

155. Whyte, M.P. Paget's Disease of Bone. N. Engl. J. Med. 2006, 355, 593-600. [CrossRef]

156. Rebel, A.; Basle, M.; Pouplard, A.; Malkani, K.; Filmon, R.; Lepatezour, A. Bone Tissue in Paget's Disease of Bone Ultrastructure and Immunocytology. Arthritis Rheum. 1980, 23, 1104-1114. [CrossRef]

157. Zimmermann, E.A.; Köhne, T.; Bale, H.A.; Panganiban, B.; Gludovatz, B.; Zustin, J.; Hahn, M.; Amling, M.; Ritchie, R.O.; Busse, B. Modifications to Nano- and Microstructural Quality and the Effects on Mechanical Integrity in Paget's Disease of Bone. J. Bone Miner. Res. 2015, 30, 264-273. [CrossRef] [PubMed]

158. Giannini, C.; Siliqi, D.; Bunk, O.; Beraudi, A.; Ladisa, M.; Altamura, D.; Stea, S.; Baruffaldi, F. Correlative Light and Scanning X-Ray Scattering Microscopy of Healthy and Pathologic Human Bone Sections. Sci. Rep. 2012, 2, 435. [CrossRef]

159. Zimmermann, E.A.; Busse, B.; Ritchie, R.O. The Fracture Mechanics of Human Bone: Influence of Disease and Treatment. Bonekey Rep. 2015, 4, 743. [CrossRef] [PubMed]

160. Karunaratne, A.; Esapa, C.R.; Hiller, J.; Boyde, A.; Head, R.; Bassett, J.H.D.; Terrill, N.J.; Williams, G.R.; Brown, M.A.; Croucher, P.I.; et al. Significant Deterioration in Nanomechanical Quality Occurs through Incomplete Extrafibrillar Mineralization in Rachitic Bone: Evidence from in-Situ Synchrotron X-ray Scattering and Backscattered Electron Imaging. J. Bone Miner. Res. 2012, 27, 876-890. [CrossRef] [PubMed]

161. Boyde, A.; Staines, K.A.; Javaheri, B.; Millan, J.L.; Pitsillides, A.A.; Farquharson, C. A Distinctive Patchy Osteomalacia Characterises Phospho1-Deficient Mice. J. Anat. 2017, 231, 298-308. [CrossRef] [PubMed] 
162. Karunaratne, A.; Boyde, A.; Esapa, C.T.; Hiller, J.; Terrill, N.J.; Brown, S.D.M.; Cox, R.D.; Thakker, R.V.; Gupta, H.S. Symmetrically Reduced Stiffness and Increased Extensibility in Compression and Tension at the Mineralized Fibrillar Level in Rachitic Bone. Bone 2013, 52, 689-698. [CrossRef]

163. Ralston, S.H.; Corral-Gudino, L.; Cooper, C.; Francis, R.M.; Fraser, W.D.; Gennari, L.; Guañabens, N.; Javaid, M.K.; Layfield, R.; O'Neill, T.W.; et al. Diagnosis and Management of Paget's Disease of Bone in Adults: A Clinical Guideline. J. Bone Miner. Res. 2019, 34, 579-604. [CrossRef]

164. Zimmermann, E.A.; Schaible, E.; Gludovatz, B.; Schmidt, F.N.; Riedel, C.; Krause, M.; Vettorazzi, E.; Acevedo, C.; Hahn, M.; Puschel, K.; et al. Intrinsic Mechanical Behavior of Femoral Cortical Bone in Young, Osteoporotic and Bisphosphonate-Treated Individuals in Low- and High Energy Fracture Conditions. Sci. Rep. 2016, 6, 21072. [CrossRef] [PubMed]

165. Rohanizadeh, R.; LeGeros, R.Z.; Bohic, S.; Pilet, P.; Barbier, A.; Daculsi, G. Ultrastructural Properties of Bone Mineral of Control and Tiludronate-Treated Osteoporotic Rat. Calcif. Tissue Int. 2000, 67, 330-336. [CrossRef]

166. Shah, F.A.; Lee, B.E.J.; Tedesco, J.; Wexell, C.L.; Persson, C.; Thomsen, P.; Grandfield, K.; Palmquist, A. Micrometer-Sized Magnesium Whitlockite Crystals in Micropetrosis of Bisphosphonate-Exposed Human Alveolar Bone. Nano Lett. 2017, 17, 6210-6216. [CrossRef] [PubMed]

167. Nancollas, G.H.; Tang, R.; Phipps, R.J.; Henneman, Z.; Gulde, S.; Wu, W.; Mangood, A.; Russell, R.G.G.; Ebetino, F.H. Novel Insights into Actions of Bisphosphonates on Bone: Differences in Interactions with Hydroxyapatite. Bone 2006, 38, 617-627. [CrossRef] [PubMed]

168. Powell, K.M.; Skaggs, C.; Pulliam, A.; Berman, A.; Allen, M.R.; Wallace, J.M. Zoledronate and Raloxifene Combination Therapy Enhances Material and Mechanical Properties of Diseased Mouse Bone. Bone 2019, 127, 199-206. [CrossRef] [PubMed]

169. Pilmane, M.; Salma-Ancane, K.; Loca, D.; Locs, J.; Berzina-Cimdina, L. Strontium and Strontium Ranelate: Historical Review of Some of Their Functions. Mater. Sci. Eng. C 2017, 78, 1222-1230. [CrossRef]

170. Brennan, T.C.; Rybchyn, M.S.; Green, W.; Atwa, S.; Conigrave, A.D.; Mason, R.S. Osteoblasts Play Key Roles in the Mechanisms of Action of Strontium Ranelate. Br. J. Pharmacol. 2009, 157, 1291-1300. [CrossRef]

171. Ammann, P.; Shen, V.; Robin, B.; Mauras, Y.; Bonjour, J.P.; Rizzoli, R. Strontium Ranelate Improves Bone Resistance by Increasing Bone Mass and Improving Architecture in Intact Female Rats. J. Bone Miner. Res. 2004, 19, 2012-2020. [CrossRef] [PubMed]

172. Li, C.; Paris, O.; Siegel, S.; Roschger, P.; Paschalis, E.P.; Klaushofer, K.; Fratzl, P. Strontium Is Incorporated into Mineral Crystals Only in Newly Formed Bone during Strontium Ranelate Treatment. J. Bone Miner. Res. 2010, 25, 968-975. [CrossRef] [PubMed]

173. Rossi, A.L.; Moldovan, S.; Querido, W.; Rossi, A.; Werckmann, J.; Ersen, O.; Farina, M. Effect of Strontium Ranelate on Bone Mineral: Analysis of Nanoscale Compositional Changes. Micron 2014, 56, 29-36. [CrossRef]

174. Doublier, A.; Farlay, D.; Jaurand, X.; Vera, R.; Boivin, G. Effects of Strontium on the Quality of Bone Apatite Crystals: A Paired Biopsy Study in Postmenopausal Osteoporotic Women. Osteoporos. Int. 2013, 24, 1079-1087. [CrossRef]

175. Falgayrac, G.; Farlay, D.; Ponçon, C.; Béhal, H.; Gardegaront, M.; Ammann, P.; Boivin, G.; Cortet, B. Bone Matrix Quality in Paired Iliac Bone Biopsies from Postmenopausal Women Treated for 12 Months with Strontium Ranelate or Alendronate. Bone 2021, 153, 116107. [CrossRef] [PubMed]

176. Yalin, S.; Comelekoglu, U.; Bagis, S.; Yilmaz, N. Effects of Strontium Ranelate on Cortical Bone Collagen Integrity. Saudi Med. J. 2012, 33, 515-519. [PubMed]

177. Vanleene, M.; Saldanha, Z.; Cloyd, K.L.; Jell, G.; Bou-Gharios, G.; Bassett, J.H.D.; Williams, G.R.; Fisk, N.M.; Oyen, M.L.; Stevens, M.M.; et al. Transplantation of Human Fetal Blood Stem Cells in the Osteogenesis Imperfecta Mouse Leads to Improvement in Multiscale Tissue Properties. Blood 2011, 117, 1053-1060. [CrossRef] [PubMed]

178. Panaroni, C.; Gioia, R.; Lupi, A.; Besio, R.; Goldstein, S.A.; Kreider, J.; Leikin, S.; Vera, J.C.; Mertz, E.L.; Perilli, E.; et al. In Utero Transplantation of Adult Bone Marrow Decreases Perinatal Lethality and Rescues the Bone Phenotype in the Knockin Murine Model for Classical, Dominant Osteogenesis Imperfecta. Blood 2009, 114, 459-468. [CrossRef]

179. Horwitz, E.M.; Prockop, D.J.; Fitzpatrick, L.A.; Koo, W.W.; Gordon, P.L.; Neel, M.; Sussman, M.; Orchard, P.; Marx, J.C.; Pyeritz, R.E.; et al. Transplantability and Therapeutic Effects of Bone Marrow-Derived Mesenchymal Cells in Children with Osteogenesis Imperfecta. Nat. Med. 1999, 5, 309-313. [CrossRef] [PubMed]

180. Baltzer, A.W.A.; Whalen, J.D.; Wooley, P.; Latterman, C.; Truchan, L.M.; Robbins, P.D.; Evans, C.H. Gene Therapy for Osteoporosis: Evaluation in a Murine Ovariectomy Model. Gene Ther. 2001, 8, 1770-1776. [CrossRef]

181. Kinoshita, Y.; Mohamed, F.F.; de Oliveira, F.A.; Narisawa, S.; Miyake, K.; Foster, B.L.; Millán, J.L. Gene Therapy Using AdenoAssociated Virus Serotype 8 Encoding TNAP-D 10 Improves the Skeletal and Dentoalveolar Phenotypes in Alpl ${ }^{-/-} \mathrm{Mice}^{-} J$. Bone Miner. Res. 2021, 36, 1835-1849. [CrossRef]

182. Niyibizi, C.; Wang, S.; Robbins, P.D. Gene Therapy Approaches for Osteogenesis Imperfecta. Gene Ther. 2004, 11, 408-416. [CrossRef]

183. Thomas, I.H.; DiMeglio, L.A. Advances in the Classification and Treatment of Osteogenesis Imperfecta. Curr. Osteoporos. Rep. 2016, 14, 1-9. [CrossRef]

184. Zhang, J.; Liu, G.H.; Qu, J.; Song, M. Treating Osteoarthritis via Gene Therapy with Rejuvenation Factors. Gene Ther. 2020, 27, 309-311. [CrossRef] [PubMed]

185. Karakoti, A.S.; Tsigkou, O.; Yue, S.; Lee, P.D.; Stevens, M.M.; Jones, J.R.; Seal, S. Rare Earth Oxides as Nanoadditives in 3-D Nanocomposite Scaffolds for Bone Regeneration. J. Mater. Chem. 2010, 20, 8912-8919. [CrossRef] 
186. Pinna, A.; Baghbaderani, M.T.; Hernández, V.V.; Naruphontjirakul, P.; Li, S.; McFarlane, T.; Hachim, D.; Stevens, M.M.; Porter, A.E.; Jones, J.R. Nanoceria Provides Antioxidant and Osteogenic Properties to Mesoporous Silica Nanoparticles for Osteoporosis Treatment. Acta Biomater. 2021, 122, 365-376. [CrossRef] [PubMed]

187. Kaplan, F.S. Surgical Management of Paget' s Disease of Bone. J. Bone Miner. Res. 1999, 14, 34-38. [CrossRef] [PubMed]

188. Autefage, H.; Allen, F.; Tang, H.M.; Kallepitis, C.; Gentleman, E.; Reznikov, N.; Nitiputri, K.; Nommeots-Nomm, A.; O’Donnell, M.D.; Lange, C.; et al. Multiscale Analyses Reveal Native-like Lamellar Bone Repair and near Perfect Bone-Contact with Porous Strontium-Loaded Bioactive Glass. Biomaterials 2019, 209, 152-162. [CrossRef]

189. Porter, A.E.; Patel, N.; Skepper, J.N.; Best, S.M.; Bonfield, W. Effect of Sintered Silicate-Substituted Hydroxyapatite on Remodelling Processes at the Bone-Implant Interface. Biomaterials 2004, 25, 3303-3314. [CrossRef]

190. Rauch, F.; Geng, Y.; Lamplugh, L.; Hekmatnejad, B.; Gaumond, M.H.; Penney, J.; Yamanaka, Y.; Moffatt, P. Crispr-Cas9 Engineered Osteogenesis Imperfecta Type V Leads to Severe Skeletal Deformities and Perinatal Lethality in Mice. Bone 2018, 107, 131-142. [CrossRef] [PubMed]

191. Iordachescu, A.; Amin, H.D.; Rankin, S.M.; Williams, R.L.; Yapp, C.; Bannerman, A.; Pacureanu, A.; Addison, O.; Hulley, P.A.; Grover, L.M. An In Vitro Model for the Development of Mature Bone Containing an Osteocyte Network. Adv. Biosyst. 2018, 2. [CrossRef]

192. Bassett, J.H.D.; Gogakos, A.; White, J.K.; Evans, H.; Jacques, R.M.; van der Spek, A.H.; Ramirez-Solis, R.; Ryder, E.; Sunter, D.; Boyde, A.; et al. Rapid-Throughput Skeletal Phenotyping of 100 Knockout Mice Identifies 9 New Genes That Determine Bone Strength. PLoS Genet. 2012, 8, e1002858. [CrossRef] [PubMed] 